DOI: $10.19195 / 0137-1134.104 .14$

\title{
ZBIGNIEW PULKA
}

Uniwersytet Wrocławski

\section{FILOZOFICZNE PRZESŁANKI POJMOWANIA SYSTEMOWOŚCI PRAWA W TEORII WYKŁADNI JERZEGO WRÓBLEWSKIEGO}

\section{ZAŁOŻENIA METATEORETYCZNE}

Teorię wykładni J. Wróblewskiego charakteryzuje postawa filozoficzna polegająca na przyjęciu założeń marksizmu w charakterze filozoficznych przesłanek działalności teoretycznej w prawoznawstwie. Odwołując się do ustaleń tego autora w kwestii relacji filozofii i teorii prawa, można powiedzieć, że pomiędzy tworzoną przezeń teorią wykładni prawa ludowego a filozofią marksistowską występuje relacja zarówno powołania, jak i przyporządkowania. Oznacza to, że związek ten ma nie tylko charakter deklaratywny (relacja powołania), lecz także merytoryczny (relacja przyporządkowania). Autor formułuje następującą definicję relacji przyporządkowania: „Twierdzenie Tp jest przyporządkowane twierdzeniu Tf wtedy i tylko wtedy, gdy z Tf da się wyprowadzić Tp na podstawie przyjętych dyrektyw wnioskowania i ewentualnie przy przyjęciu innych twierdzeń Te mających charakter analityczny lub syntetyczny". "Z kolei, dyrektywy wnioskowania, o których mowa w cytowanej definicji to: ,[...] dyrektywy logiki sensu largissimo, które obejmują nie tylko wywodzenie zdań ze zdań lecz również norm i ocen"2. W nieco innym ujęciu, autor ów, charakteryzując relację przyporządkowania, wskazuje, że zachodzi ona wówczas, gdy pomiędzy tezami teorii prawa i tezami filozofii występują „zależności logiczne sensu largo"3. Podkreślając funkcję heurystyczną filozofii wobec teorii prawa, autor wskazuje, że w przypadku marksistowskiej teorii prawa, związki teorii i filozofii mają charakter dedukcyjny, ponieważ teoria ta jest wyprowadzana $\mathrm{z}$ określonego zespołu założeń filozoficzno-metodolo-

1 J. Wróblewski, Filozoficzne problemy teorii prawa (Rozważania metodologiczne), „Państwo i Prawo" 1974, nr 11, s. 6.

2 J. Wróblewski, Postawa filozoficzna i afilozoficzna we wspótczesnej teorii prawa, „Studia Prawnicze" 1966, z. 13, s. 74.

3 Ibidem, s. 70. 
gicznych i może być ujmowana jako część systemu filozoficznego marksizmu4 Ujęcie omawianych zależności jako tych o charakterze dedukcyjnym wskazuje, że założenia filozoficzne są punktem wyjścia przy formułowaniu twierdzeń teoretycznych, które mogą być ujmowane jako konsekwencje logiczne (quasi-logiczne) przyjętych założeń filozoficznych. W takim ujęciu, proces budowy teorii prawa przebiega „z góry do dołu”. Punktem wyjścia procesu poznawczego są ogólne rozstrzygnięcia filozoficzne o charakterze ontologicznym, epistemologicznym i aksjologicznym, których przyjęcie przesądza rozstrzygnięcia przynajmniej niektórych zagadnień prawnych dokonywanych na niższym szczeblu ogólności teorii prawa ${ }^{5}$. Ujęcie zależności pomiędzy filozofią i teorią prawa jako zależności o charakterze dedukcyjnym, wskazuje, że założenia filozoficzne są pierwotne poznawczo wobec twierdzeń teorii prawa. Przyjęte w marksistowskiej metodologii nauk pojęcie pierwotności poznawczej wskazuje, że relacja ta zachodzi wówczas, gdy twierdzenia T2 (poznawczo wtórne) zakładają model rzeczywistości określony przez twierdzenia T1 (poznawczo pierwotne) ${ }^{6}$. W analizowanym przypadku, twierdzenia $\mathrm{T} 2$ to twierdzenia teoretycznoprawne, a twierdzenia $\mathrm{T} 1$ to twierdzenia filozoficzne. Oznaczałoby to, że twierdzenia marksistowskiej teorii prawa jako poznawczo wtórne, zakładają model rzeczywistości określony na poziomie pierwotnych poznawczo twierdzeń filozoficznych marksizmu jako systemu filozoficznego. Zgadzając się z tezą, że filozofia pełni wobec teorii prawa przede wszystkim funkcję heurystyczną, można by uznać, że pierwotne poznawczo twierdzenia filozoficzne pełnią w procesie budowy teorii prawa funkcję ,programu heurystycznego" 7 . Oznaczałoby to, że pierwotne poznawczo rozstrzygnięcia ontologiczne, epistemologiczne i aksjologiczne, determinują pole dla dokonywania poznawczo wtórnych rozstrzygnięć teoretycznoprawnych i w ten sposób sprzyjają (lub nie) tworzeniu wartościowych teorii prawa.

Warto zwrócić uwagę, że J. Wróblewski dla charakterystyki relacji przyporządkowania używa określeń: „zależności logiczne sensu largo” czy też: „dyrektywy logiki sensu largissimo". Użycie ich wskazuje, że w grę wchodzą tu nie tylko zależności o charakterze formalnym (dedukcyjnym), lecz także nieformalne o charakterze argumentacyjnym, zaliczane do kategorii tak zwanych ,miękkich strategii argumentacyjnych" ". Zdaniem autora niniejszego opracowania, szczególnie interesujące może być zinterpretowanie relacji przyporządkowania jako presupozycji,

${ }^{4}$ Ibidem, s. 82; por. też, J. Woleński, Z zagadnień analitycznej filozofii prawa, Kraków 1980, s. $14 \mathrm{n}$.

5 J. Wróblewski, The concept of legal philosophy, [w:] Sur la Philosophie de Droit, red. R. Lukić, Belgrad 1978, s. 311-312.

${ }^{6}$ J. Kmita, Uwagi o holizmie marksowskim jako koncepcji metodologicznej, [w:] Założenia metodologiczne ,Kapitału” Marksa, Warszawa 1970, s. 69-71.

${ }^{7}$ H. Eilstein, Hipotezy ontologiczne i orientacje ontologiczne, [w:] Teoria i doświadczenie, red. H. Eilstein, M. Przełęcki, Warszawa 1966, s. 230-231.

$8 \mathrm{Na}$ nieformalny charakter relacji przyporządkowania wskazuje P. Jabłoński, Polskie spory o role filozofii w teorii prawa, Wrocław 2014, s. 94-97. 
w której twierdzenia teoretycznoprawne presuponują określone tezy filozoficzne. Jak wiadomo, wyróżnia się presupozycje semantyczne (logiczne) i pragmatyczne ${ }^{9}$. W pierwszym przypadku można powiedzieć, że zdanie A presuponuje zdanie B wtedy, gdy prawdziwość B jest warunkiem prawdziwości zdania A i jego negacji (nie A) ${ }^{10}$. W drugim przypadku: „Mówca presuponuje pragmatycznie B w danym momencie konwersacji, w przypadku, gdy skłonny jest działać językowo tak, jak gdyby uznawał prawdziwość B za oczywistą i zakładał, że jego słuchacze wiedzą o tym" ${ }^{11}$. Jakkolwiek obydwa ujęcia presupozycji mogą być przydatne dla charakterystyki relacji pomiędzy teorią prawa i filozofią, w przypadku marksistowskiej teorii prawa za szczególnie istotne autor autor niniejszej pracy uważa jednak ujęcie tych relacji w kategoriach presupozycji o charakterze semantycznym. Warto bowiem zwrócić uwagę, że dla charakterystyki presupozycji semantycznych podstawowe znaczenie ma tak zwana oporność na negację, czyli że presupozycje te są implikowane zarówno przez dany sąd, jak i jego negację. Jest tak, ponieważ presupozycje te to założone sądy egzystencjalne stwierdzające istnienie obiektów (zdanie B), o których orzekają sądy stwierdzające właściwości tych obiektów (zdanie A). Odnosząc takie rozumienie presupozycji do relacji pomiędzy teorią prawa i filozofią, powiemy zatem, że wspomniana relacja zachodzi wówczas, gdy twierdzenia teorii prawa presuponują istnienie obiektów określonych przez przyjęte założenia filozoficzne. W przypadku marksistowskiej teorii prawa, twierdzenia tej teorii presuponują istnienie pewnego świata (rzeczywistości społecznej) określonej na poziomie przyjętych założeń filozoficznych. Odnosząc te rozważana do teorii wykładni J. Wróblewskiego, jako teorii wyrażającej marksistowską postawę filozoficzną, można powiedzieć, że teoria ta presuponuje istnienie pewnego świata, którego podstawowe cechy są określone przez twierdzenia materializmu dialektycznego i historycznego. Warto zaznaczyć, że zarówno istnienie tego świata, jak i jego podstawowe cechy, są przesądzone na poziomie założeń filozoficznych, które stanowią punkt wyjścia działalności teoretycznoprawnej i w tym sensie poznawczo pierwotne wobec teorii prawa.

\section{POZIOM ZAŁOŻEŃ FILOZOFICZNYCH ORAZ ICH TEORETYCZNO-PRAWNYCH KONSEKWENCJI}

Teoria wykładni J. Wróblewskiego jest teorią wykładni „prawa ludowego" (prawa socjalistycznego-komunistycznego). Oznacza to, że jej twierdzenia presuponują w sensie semantycznym (logicznym) istnienie obiektu, do którego odnosi

${ }^{9}$ M. Smolak, Wyktadnia celowościowa z perspektywy pragmatycznej, Warszawa 2012, s. 224 n.

10 J. Woleński, op. cit., s. 51-52.

11 M. Smolak, op. cit., s. 227; por. też R. Sarkowicz, Poziomowa interpretacja tekstu prawnego, Kraków 1995, s. 136; na pragmatyczny charakter presupozycji wskazuje J. Wróblewski, Presupozycje rozumowań prawniczych, „Studia Prawno-Ekonomiczne” XXXVII, 1986, s. 8-9. 
się nazwa „prawo ludowe”. Trzeba szczególnie podkreślić, że w przekonaniu autora niniejszej pracy, termin ,prawo ludowe" wskazuje na kategorię filozoficzną, to znaczy że podstawowe cechy obiektu będącego desygnatem tego terminu są określone na poziomie poznawczo pierwotnych założeń filozoficznych marksizmu. Powstaje zatem pytanie: jakie cechy zjawisk prawnych („prawa ludowego”) są w omawianym przypadku przesądzone przez przyjęcie pierwotnych poznawczo założeń filozoficznych marksizmu?

Nie wdając się w szczegółowe omawianie założeń filozofii marksistowskiej, należy podkreślić, że jest to filozofia dialektyczna, to znaczy taka, która ma programowo przełamywać tradycyjne opozycje, takie jak opozycja bytu i myślenia, bytu i powinności oraz poznania i wartościowania ${ }^{12}$. Podstawowym rozstrzygnięciem filozoficznym (eschatologicznym) marksizmu jest teza, że historia to proces celowy i jako taka stanowi proces postępu polegającego na przejściu od bytu niższego rzędu (byt dotknięty alienacją w społeczeństwach klasowych) do bytu wyższego rzędu (byt wolny od alienacji w społeczeństwie komunistycznym - ludowym). Według marksistów, teza ta jednoczy poznanie i wartościowanie. Ma sens poznawczy (deskryptywny), ponieważ opisuje proces ewolucji bytu społecznego (w tym sensie jest też tezą ontologiczną określającą podstawową prawidłowość bytu społecznego). Ma również sens wartościujący, ponieważ jest równoznaczna z uznaniem bytu dotkniętego alienacją za największe zło, z jednoczesnym uznaniem bytu wolnego od alienacji (komunizm-społeczeństwo ludowe) za największe dobro (w tym sensie jest to teza aksjologiczna określająca hierarchię wartości). W konsekwencji, byt niższego rzędu zawiera w sobie powinność jego destrukcji, a byt wyższego rzędu powinność jego tworzenia (jedność bytu i powinności). Marksistowska teoria rozwoju społecznego jest jednocześnie teorią postępu etycznego, to znaczy zawiera w sobie etykę postępu poprzez sformułowanie podstawowych ocen pierwotnych (niezrelatywizowanych) i związanych z nimi dyrektyw działania (etyka normatywna). Uznanie eschatologii ostatecznego pojednania bytu za podstawowe rozstrzygnięcie w marksistowskim systemie wiedzy dialektycznej, przesądza o obrazie „prawa ludowego”, którego główne cechy są określone na poziomie założeń filozoficznych. Dlatego pojęcie ,prawa ludowego" jest kategorią filozoficzną, czyli pozbawioną sensu empirycznego. W teorii wykładni J. Wróblewskiego twierdzenia filozoficzne określające obraz „,prawa ludowego", funkcjonują w charakterze pierwotnych poznawczo-filozoficznych presupozycji. Pojęcia presupozycji użyto tu w sensie mocnym (semantycznym), co oznacza, że twierdzenia te mają charakter twierdzeń egzystencjalnych, konstytuujących istnienie obiektu o określonych właściwościach. Twierdzenia te są następujące:

1. Prawo ludowe ma być skutecznym narzędziem, którego użycie przyspieszać ma obiektywny proces dziejowy stawania się wyższej formy społecznego

12 Wskazane właściwości marksistowskiego modelu wiedzy dialektycznej omówiono w pracy Z. Pulka, Legitymizacja państwa w prawoznawstwie, Wrocław 1996, s. 13-32. 
istnienia, jaką jest komunizm pojmowany jako byt wolny od alienacji, w którym następuje pełne uspołecznienie człowieka ${ }^{13}$. W warunkach wyższej formy społecznego istnienia, prawo ludowe przestaje być formą mediacji sprzecznych interesów klasowych, stając się narzędziem tworzenia społecznej jedności. Oznacza to przyjęcie instrumentalnej koncepcji prawa jako narzędzia w rękach decydentów politycznych (prawodawcy). Prawo ludowe jest narzędziem globalnej przebudowy społecznej, która polega na tworzeniu bytu wyższego rzędu (społeczeństwo komunistyczne). Uprzywilejowany poznawczo prawodawca, który dysponuje wyróżnioną wiedzą na temat ostatecznego celu prawa, określając cele pośrednie, nie czyni tego w sposób dowolny, ponieważ wybór celów pośrednich jest podporządkowany realizacji celu ostatecznego, zdefiniowanego przez eschatologię ostatecznego pojednania bytu. Ten cel ostateczny jest określony przez rozum (logos) dziejowy, który przybiera postać obiektywnych praw rozwoju społecznego. Jedność teleologiczna systemu prawa ludowego polega właśnie na jego roli jako skutecznego środka realizacji celu ostatecznego wyznaczonego przez rozum dziejowy ${ }^{14}$.

2. W ścisłym związku z instrumentalną wizją prawa pozostaje przyjęcie tetycznej koncepcji obowiązywania prawa. Podstawą obowiązywania prawa ludowego jest akt stanowienia przez uprzywilejowanego poznawczo prawodawcę. W konsekwencji, rozstrzygające dla uznania normy prawnej za obowiązującą są jej cechy formalne, to znaczy zgodność aktu stanowienia z normami kompetencji prawodawczej i procedury prawodawczej. Prowadzi to do uznania koncepcji obowiązywania systemowego normy za rozstrzygającą przy rozwiązywaniu problemów walidacyjnych w systemie prawa ludowego ${ }^{15}$.

3. Treść prawa ludowego ma wyrażać wolę klasy panującej, którą artykułuje uprzywilejowana poznawczo awangarda tej klasy (prawodawca). Na tym ma polegać jedność socjologiczna systemu prawa ludowego ${ }^{16}$. Treść prawa ludowego jest zatem w pełni określona odgórnie przez uprzywilejowanego poznawczo prawodawcę i nie ma charakteru dyskursywnego, to znaczy nie może być określana w dyskursie prawniczym, w szczególności w dyskursie aksjologicznym dotyczącym pojmowania sprawiedliwości, słuszności czy uczciwego procesu. Wszystkie kwestie aksjologiczne prawa ludowego są rozstrzygnięte odgórnie przez ideologię socjalistyczną, czyli przez pierwotne poznawczo założenia filozoficzne, w których określony jest system ocen pierwotnych (niezrelatywizowanych) ${ }^{17}$. Zdefiniowane na poziomie założeń filozoficznych wartości pierwotne

13 W. Lang, J. Wróblewski, Aksjologia prawa socjalistycznego, [w:] Prawo socjalistyczne, red. H. Rot, Wrocław 1989, rozdz. 3, passim.

14 W. Lang, J. Wróblewski, S. Zawadzki, Teoria państwa i prawa, Warszawa 1986, s. 390.

15 Ibidem.

16 Ibidem.

17 Ibidem, s. 32. 
są zakodowane w postaci spójnego systemu wartości wewnętrznych prawa ludowego ${ }^{18}$.

4. Ten spójny system wartości wewnętrznych prawa ludowego precyzuje nową formę życia, której powszechną akceptację przez interpretatorów zakłada ideologia wykładni prawa ludowego ${ }^{19}$. Zgodnie z tą ideologią, w dyskursie prawniczym obowiązuje imperatyw formułowania ocen zrelatywizowanych do systemu wartości wyznaczonego przez etykę postępu ${ }^{20}$. W procesie określania treści prawa, uprzywilejowani poznawczo decydenci polityczni (prawodawca) nie są ograniczeni zastaną moralnością należącą do niższej formy bytu (kapitalizm). Prawo ludowe jest narzędziem tworzenia nowej (wyższej) moralności określonej przez etykę postępu ${ }^{21}$. W konsekwencji, podstawowe kwestie aksjologiczne w prawie rozstrzyga prawodawca, a nie dyskurs prawniczy (dyskurs interpretacyjny). Odrzucenie dyskursywnej koncepcji prawa jest następstwem jego instrumentalizacji. Jeżeli prawo ma być skutecznym narzędziem tworzenia jedności społecznej, to wówczas podstawowe elementy jego treści (a zwłaszcza treści aksjologiczne) nie mogą być przedmiotem niekończących się debat w doktrynie i orzecznictwie.

5. Zgodnie $\mathrm{z}$ instrumentalną i niedyskursywną koncepcją prawa ludowego, decydowanie o tym, co jest, a co nie jest prawem obowiązującym, zastrzeżono dla prawodawcy (uprzywilejowanych poznawczo decydentów politycznych). W szczególności, kwestii tych nie mogą rozstrzygać podmioty stosujące prawo czy też podmioty dokonujące interpretacji tekstów prawnych. Marksistowska koncepcja prawa ludowego zakłada zatem radykalne oddzielenie tworzenia i stosowania prawa. Rola podmiotów stosujących prawo (interpretatorów) w zakresie określania treści prawa powinna być minimalna, ponieważ monopol na określanie treści prawa ma uprzywilejowany poznawczo prawodawca. Towarzyszy temu założenie, że treść prawa ludowego jest dostatecznie precyzyjnie określona w aktach stanowienia prawa. Stąd radykalna krytyka prawotwórstwa sądowego oraz wykluczenie możliwości podejmowania decyzji praeter lub contra legem przez podmioty stosujące prawo ${ }^{22}$. W konsekwencji, wykładnia jest aktem odtwórczym, a nie twórczym.

18 J. Wróblewski, Wartości a decyzja sądowa, Wrocław 1973, s. 47 n.

19 W. Lang, J. Wróblewski, S. Zawadzki, op. cit., s. 485.

$20 \mathrm{Na}$ temat etyki postępu por. J. Wróblewski, Rozumność rzeczywistości w Heglowskiej filozofii prawa a dualizm bytu i powinności, „Zaszyty Naukowe Uniwersytetu Łódzkiego”, Nauki Humanistyczno-Społeczne, Seria I, zeszyt 52, Łódź 1957, s. 16-17; por. też idem, Relatywistyczne teorie prawa, „Państwo i Prawo” 1963, nr 8-9, s. 218-219; por. też idem, Teoria racjonalnego tworzenia prawa, Wrocław 1985, s. 227-230.

21 J. Wróblewski, Zagadnienia teorii wyktadni prawa ludowego, Warszawa 1959, s. 389; por. też idem, Stosunki między systemami norm, „Studia Prawno-Ekonomiczne” 1971, z. 6, s. 31-32; idem, Relatywistyczne teorie..., passim.

22 J. Wróblewski, Modele systemów norm a system prawa, „Studia Prawno-Ekonomiczne” 1969, z. 2, s. 46-47; idem, Sądowe stosowanie prawa a prawotwórstwo, „Państwo i Prawo” 1967, 
W marksistowskiej teorii prawa ludowego, prawo nie jest faktem interpretacyjnym, lecz imperatywnym, to znaczy odgórnie określonym przez prawodawcę.

6. Prawo jako narzędzie globalnej zmiany społecznej jest systemem, to znaczy uporządkowanym zbiorem norm prawnych postrzeganych jako wypowiedzi językowe, które określają wiążące wzory zachowań. Prawo ludowe, jako system, cechuje wysoki poziom spójności socjologicznej (wyrażenie woli klasy panującej) i teleologicznej (tworzenie wyższej formy bytu jako globalny cel prawa). W konsekwencji system prawa ludowego charakteryzuje koherencja aksjologiczna (wartości wewnętrzne prawa tworzą spójny wewnętrznie system określony przez etykę postępu) oraz wysoki poziom spójności formalnej (więzi pionowe związane z hierarchią autorytetów normodawczych), a także materialnej (normy zwykłe są treściowo zgodne z normami zasadniczymi ${ }^{23}$. Konsekwencją przyjęcia instrumentalnej wizji prawa jako narzędzia globalnej przebudowy społecznej jest uznanie systemowości za cechę immanentną prawa ludowego. Oznacza to, że prawo nie staje się systemem w procesie optymalizacyjnej egzegezy tekstów prawnych, lecz dane jest jako system w wyniku działań prawodawcy. Inaczej mówiąc, system prawa jest dziełem prawodawcy a nie interpretatora dokonującego systematyzacji prawa. Warto podkreślić, że w marksistowskiej teorii prawa, systemowość prawa ma zdecydowanie konotację ontologiczną, a nie epistemologiczną. System jest konieczną formą istnienia prawa ludowego, to znaczy prawo to bytuje jako system, czy też może bytować (istnieć) tylko w formie systemu norm. Kategoria systemu opisuje sposób istnienia prawa, a nie jest, jako kategoria epistemologiczna, narzędziem poznania prawa czy też koniecznym założeniem w procesie jego optymalizacji. Systemowość prawa ma w marksistowskiej teorii i filozofii prawa interpretację realistyczną, nie zaś instrumentalną ${ }^{24}$.

Autor niniejszego opracowania twierdzi, że przyjęcie tych podstawowych elementów marksistowskiej filozofii prawa w charakterze pierwotnych poznawczo założeń filozoficznych (presupozycji) przesądza o sposobie pojmowania systemowości prawa ludowego w teorii wykładni J. Wróblewskiego.

z. 6, passim; por. też idem, Interpretatio secundum, praeter et contra legem, „Państwo i Prawo” 1961, z. 4-5, passim.

23 W. Lang, J. Wróblewski, S. Zawadzki, op. cit., s. 389-390.

24 J. Wróblewski, Pojęcie systemu prawa a informatyka prawnicza, „Studia Prawno-Ekonomiczne” XXV, 1980, passim; idem, Modele systemów..., passim; idem, Stosunki..., passim; idem, Decyzja sądowa a koncepcja systemu prawa, „Zeszyty Naukowe Uniwersytetu Łódzkiego, Nauki Humanistyczno-Społeczne", Seria I, 1978, z. 28, passim; idem, Concepts of legal system and conceptions of validity, „Acta Universitatis Lodziensis, Folia Iuridica, 24, 1986, passim; idem, Ustawa o tworzeniu prawa a pojęcie prawa i prawoznawstwa, „Państwo i Prawo” 1977 nr 8-9, passim; idem, Obowiązywanie systemowe i granice dogmatycznego podejścia do systemu prawa, „Studia Prawno-Ekonomiczne” XXXVI, 1986, passim; idem, Nieostrość systemu prawa, „Studia Prawno-Ekonomiczne” XXXI, 1989, passim. 


\section{POZIOM TEORII WYKŁADNI}

Przyjęcie omówionych powyżej założeń, w charakterze pierwotnych poznawczo presupozycji filozoficznych, powoduje, że teorię wykładni J. Wróblewskiego charakteryzuje silne dążenie do obiektywizacji prawa. W omawianej teorii wykładni przyjmuje się, że określona na poziomie pierwotnych poznawczo założeń filozoficznych kategoria „prawo ludowe”, wskazuje na istniejącą obiektywnie realność społeczną, charakteryzującą się wyżej wskazanymi cechami. Termin „istnienie obiektywne" jest tu rozumiany jako istnienie niezależne od podmiotu poznającego, którym w tym przypadku jest interpretator. W szczególności, autor przyjmuje, że reguła prawna sformułowana w określonym języku, istnieje obiektywnie i jako taka nie jest tożsama ze swoim znaczeniem, które stanowi wzór zachowania $^{25}$. A zatem norma (prawo) to coś więcej niż tylko identyfikowany w procesie jej rozumienia wzór zachowania. W konsekwencji, zmiana znaczenia w wyniku wykładni nie jest równoznaczna ze zmianą normy jako bytu obiektywnego, określonego w następstwie działań prawodawcy. Oznacza to, że norma (prawo) jako byt obiektywny powołany do istnienia aktem prawodawcy, istnieje niezależnie od aktów interpretacji prawa. Co więcej, autor konsekwentnie, we wszystkich fazach tworzenia swojej teorii wykładni podtrzymuje założenie, że również znaczenie normy w postaci wzoru zachowania, jest zawsze, przynajmniej w pewnym stopniu, niezależne od interpretatora ${ }^{26}$. Prawo (norma) nie jest zatem faktem interpretacyjnym definiowanym $\mathrm{w}$ procesie wykładni, lecz imperatywnym, zdefiniowanym w aktach tworzenia prawa dokonanych przez prawodawcę. Podobnie jak reguła prawna, również system prawa jako uporządkowany zbiór tych reguł istnieje obiektywnie, to znaczy niezależnie od aktów interpretacji tekstów prawnych. Podobnie jak znaczenie normy, również określony poziom uporządkowania systemowego norm jest zdeterminowany poprzez dokonywane przez prawodawcę akty tworzenia prawa, a nie poprzez dokonywane przez interpretatora akty wykładni prawa. W konsekwencji, założenie o obiektywnym istnieniu systemu prawa jest podstawową presupozycją egzystencjalną działań interpretacyjnych, przyjętą na poziomie pierwotnych poznawczo założeń filozoficznych. Oznacza to, że systemowość prawa nie stanowi efektu interpretacji jako czynności optymalizacyjnej, to znaczy maksymalizującej wartość przedmiotu interpretacji (tekstu prawnego). Wręcz odwrotnie, założenie systemowości prawa jest punktem wyjścia działań interpretacyjnych jako podstawowa charakterystyka ontologiczna prawa ludowego. Założenie systemowości prawa to zatem stwierdzenie sposobu istnienia prawa, a nie pojęciowe narzędzie służące poznaniu prawa w procesie wykładni jako czynności optymalizacyjnej. Zgodnie z pierwotnymi poznawczo założeniami filozoficznymi ujmującymi prawo jako narzędzie tworzenia wyższej for-

25 J. Wróblewski, Zagadnienia..., s. 140.

26 J. Wróblewski, Rozumienie prawa i jego wykładnia, Wrocław 1990, s. 111-112. 
my społecznego istnienia, w teorii wykładni J. Wróblewskiego, kategoria systemu prawa funkcjonuje jako ontologiczna - określająca sposób istnienia prawa, a nie epistemologiczna, czyli określająca sposób poznania prawa. W konsekwencji, na gruncie omawianej teorii wykładni, norma jako znacząca wypowiedź językowa musi być zawsze postrzegana jako należąca do systemu prawa. Systemowość jest cechą definicyjną normy, ponieważ normę określa się jako znaczącą wypowiedź językową należącą do systemu prawa. Pojedyncza norma jest zatem bytem systemowym w tym sensie, że jej istnienie jest niemożliwe poza systemem prawa. Wynika to chociażby z przyjęcia systemowej koncepcji obowiązywania normy ${ }^{27}$. W konsekwencji, postrzeganie normy jako bytu systemowego determinuje działania interpretatora nie tylko w trakcie właściwej wykładni systemowej, lecz także w trakcie wykładni językowej i funkcjonalnej. Inaczej mówiąc, charakterystyczną cechą omawianej teorii wykładni jest uwzględnianie kontekstu systemowego również wtedy, gdy, ustalając znaczenie normy, interpretator odwołuje się do kontekstu językowego i funkcjonalnego interpretowanej normy. Oznacza to, że założenie systemowości normy jest stale obecne w procesie ustalania jej znaczenia w postaci wzoru zachowania.

Na gruncie omawianej teorii wykładni, w ramach wykładni językowej, założenie systemowości prawa znajduje wyraz w formie postulatu spójności semantycznej tekstu prawnego. W przypadku wykładni językowej, interpretator, ustalając znaczenie normy, odwołuje się do jej kontekstu językowego, czyli do mniej lub bardziej oczywistych właściwości języka prawnego. W teorii wykładni J. Wróblewskiego, za jedną z bardziej oczywistych właściwości języka prawnego uznaje się określony poziom jego spójności semantycznej, to znaczy zakłada się, że równokształtne wyrażenia w tekście prawnym mają to samo znaczenie. Założenie to występuje $\mathrm{w}$ formie postulatu, zgodnie $\mathrm{z}$ którym równokształtne zwroty językowe występujące w tekście prawnym powinny być jednakowo rozumiane. Postulat spójności semantycznej tekstu prawnego jest wyrażony w większości proponowanych przez J. Wróblewskiego dyrektyw wykładni językowej. Można przyjąć, że postulat ten we wspomnianych dyrektywach wyrażono wprost lub pośrednio. Wprost wyraża go dyrektywa, którą można określić jako zakaz wykładni homonimicznej i która jest oparta na założeniu, że w tekście prawnym nie ma homonimów. W omawianej teorii wykładni zakaz ten występuje w wersji wąskiej i szerokiej. W pierwszym przypadku, zakres zakazu jest ograniczony do danego aktu prawnego: „Nie można nadawać identycznym sformułowaniom w ramach tego samego aktu prawnego różnego znaczenia" 28 . W drugim przypadku ograniczenie to nie występuje i zakaz wykładni homonimicznej brzmi następująco: „Bez uzasadnionych powodów nie powinno się przypisywać różnych znaczeń temu sa-

27 Ibidem, s. 11.

28 J. Wróblewski, Zagadnienia..., s. 247; por. też K. Opałek, J. Wróblewski, Zagadnienia teorii prawa, Warszawa 1969, s. 247; por. też W. Lang, J. Wróblewski, S. Zawadzki, op. cit., s. 443. 
memu zwrotowi używanemu w regułach prawnych" ${ }^{29}$. Można przyjąć, że w tej wersji zakaz wykładni homonimicznej odnosi się do tekstu prawnego pojmowanego jako zbiór tekstów wszystkich aktów prawnych obowiązujących w danym miejscu i czasie (konkretny system prawa).

W formie pośredniej postulat spójności semantycznej tekstu prawnego wyraża się w dwóch podstawowych dyrektywach wykładni językowej, jakimi w omawianej teorii wykładni są dyrektywy określane mianem domniemania języka potocznego i domniemania języka prawnego. Dyrektywy te zakazują przypisywania „bez dostatecznych powodów” interpretowanym zwrotom swoistego znaczenia prawnego, gdy znaczenie to jest określone przez język potoczny (domniemanie języka potocznego), lub swoistego znaczenia terminologicznego należącego do terminologii części systemu prawa (gałęzi prawa), w przypadku gdy znaczenie to jest określone przez język prawny, na przykład przez definicję legalną (domniemanie języka prawnego). Warto zwrócić uwagę, że odstępstwo od tych domniemań jest możliwe tylko pod warunkiem ,dostatecznie szerokiego rozważenia znaczenia równokształtnych zwrotów w normach należących do danego systemu prawa lub jego części" ${ }^{30}$. Wspólnym elementem obu tych dyrektyw jest dążenie do ograniczenia swobody interpretatora w zakresie kreacji nowych znaczeń, w przypadku gdy znaczenia te są już ustalone na gruncie reguł języka potocznego (domniemanie 1) lub na gruncie reguł języka prawnego (domniemanie 2). Co ważne, znaczenie obu tych domniemań nie jest jednakowe dla zachowania spójności semantycznej tekstu prawnego. Dzieje się tak, ponieważ poziom zdefiniowania dyrektyw sensu w języku potocznym jest znacznie mniejszy niż w języku prawnym, w którym pewna część tych dyrektyw jest określona $\mathrm{w}$ formie definicji legalnych. Przyjmując, że podstawowym sposobem określenia znaczenia przez język prawny jest definicja legalna, dyrektywę drugą należy rozumieć jako domniemanie uniwersalnego zakresu stosowalności definicji legalnych, to znaczy należy domniemywać, że zasięg stosowalności definicji legalnych obejmuje cały system prawa. Jakkolwiek J. Wróblewski nie rozwija tej kwestii, wydaje się że można jednak rozróżnić warianty radykalny (maksymalistyczny) i umiarkowany (realistyczny) domniemania języka prawnego. W pierwszym przypadku, postulat uniwersalnego zakresu stosowalności odnosiłby się do każdej definicji legalnej. $\mathrm{W}$ takim ujęciu nie jest on akceptowany ani przez doktrynę, ani przez praktykę prawniczą, ponieważ nie stanowi postulatu realistycznego. W drugim przypadku postulat ów odnosiłby się tylko do tak zwanych „źródłowych definicji legalnych”, czyli tych zawartych w przepisach będących źródłem danej instytucji prawnej, na przykład definicja „broni palnej” zawarta w ustawie o broni i amunicji ${ }^{31}$.

29 J. Wróblewski, Rozumienie..., s. 79.

30 J. Wróblewski, Zagadnienia..., s. 246; por. też W. Lang, J. Wróblewski, S. Zawadzki, op. cit., s. 443; por. też, K. Opałek, J. Wróblewski, op. cit., s. 247.

31 Szerzej na ten temat, por. Z. Pulka, Zagadnienie spójności semantycznej systemu prawa w klaryfikacyjnej teorii wyktadni, „Przegląd Prawa i Administracji” 102, Postanalityczna filozofia prawa, Wrocław 2015, passim. 
Jak już wspomniano, w omawianej teorii wykładni założenie systemowości prawa interweniuje $\mathrm{w}$ proces ustalania znaczenia normy w przypadku wykładni odwołującej się do kontekstu językowego, systemowego oraz funkcjonalnego. Na poziomie wykładni językowej założenie systemowości prawa przejawia się $\mathrm{w}$ formie postulatu spójności semantycznej tekstu prawnego. Z kolei, na poziomie wykładni systemowej i funkcjonalnej założenie systemowości prawa obejmuje następujące kwestie: 1) elementy systemu oraz jego zakres, 2) zagadnienie niesprzeczności i zupełności systemu prawa.

Określone rozstrzygnięcia obydwu tych kwestii zakłada podstawowa dyrektywa wykładni systemowej: „Interpretator powinien tak ustalić znaczenie interpretowanej normy, by nie pociągało to za sobą sprzeczności technicznej między normą interpretowaną a jakąkolwiek z norm należących do tego samego systemu prawa" 32 . Dyrektywa ta zakłada pojęcie normy należącej do systemu prawa, które należy rozumieć jako tożsame z pojęciem normy obowiązującej. Dyrektywa ta przyjmuje zatem określone rozumienie systemu prawa obowiązującego, które jest przedmiotem wykładni. Powstaje zatem zasadnicze pytanie: jakie rozumienie systemu prawa obowiązującego zakłada podstawowa dyrektywa wykładni systemowej, która nakazuje prowadzenie interpretacji normy w sposób pozwalający na uniknięcie sprzeczności technicznych z pozostałymi normami tworzącymi system prawa obowiązującego? Na gruncie omawianej teorii wykładni, norma należąca do systemu (norma obowiązująca) musi spełniać dwa warunki: 1) jest to norma ogólna (generalna i abstrakcyjna, 2) norma ogólna musi spełniać kryteria określone przez pojęcie obowiązywania systemowego.

Rozstrzygnięcie pierwsze jest o tyle ważne, że wyklucza poza system prawa normy będące wynikiem stosowania prawa (normy indywidualne i konkretne). Jest to związane z charakterystycznym dla omawianej teorii radykalnym rozgraniczeniem tworzenia i stosowania prawa, co wiąże się ściśle z równie radykalnym zanegowaniem prawotwórstwa sądowego ${ }^{33}$. Skutkuje to także odrzuceniem Kelsenowskiej koncepcji systemu dynamicznego, która relatywizuje tworzenie i stosowanie prawa, uznając za elementy systemu dynamicznego normy merytoryczne powstałe $\mathrm{w}$ wyniku zrealizowania norm kompetencji prawodawczej. W konsekwencji, za nie do przyjęcia zostaje uznana radykalna wersja systemu prawa operatywnego (LSOP, w innej wersji LSOL), która włącza doń normy powstałe w wyniku decyzji stosowania prawa. Powodem są zarówno względy ideologiczne (ideologia praworządnej i racjonalnej decyzji sądowej zakłada radykalne odróżnienie prawotwórstwa i stosowania prawa), jak i operatywne, to znaczy brak możliwości określenia granic systemu ${ }^{34}$.

32 W. Lang, J. Wróblewski, S. Zawadzki, op. cit., s. 444; por. też, J. Wróblewski, Zagadnienia..., s. 298

33 J. Wróblewski, Modele systemów norm..., s. 46-47; idem, Sądowe stosowanie prawa a prawotwórstwo, passim.

34 J. Wróblewski, Decyzja sądowa..., s. 23 n.; idem, Ustawa o tworzeniu prawa..., s. 28-31; idem, Sadowe stosowanie..., passim. 
Rozstrzygnięcie drugie zakłada, że o przynależności normy do systemu decydują kryteria określone przez pojęcie obowiązywania systemowego normy. Zgodnie z nim, norma obowiązuje, jeżeli: (a) została ustanowiona zgodnie z normami obowiązującymi w systemie i weszła w życie, (b) lub jest konsekwencją norm należących do systemu, uznaną ze względu na reguły systemu, (c) nie została formalnie derogowana, (d) nie jest sprzeczna z żadną z norm obowiązujących w systemie, a jeżeli jest, to nie traci mocy obowiązującej na podstawie uznanych dyrektyw kolizyjnych lub nie zmienia znaczenia przez zastosowanie dyrektyw wykładni (w innej wersji - lub też została zinterpretowana w taki sposób, że nie jest sprzeczna z żadną regułą obowiązującą w systemie) $)^{35}$.

Przyjęcie koncepcji obowiązywania systemowego zakłada, że system charakteryzuje się ,zupełnością obowiązywania”, to znaczy że o dowolnej normie można orzec, czy należy do systemu. Jest to możliwe, ponieważ przyjmuje się, że do systemu należy tylko taka norma, która została ustanowiona w sposób wyznaczony przez normę należącą do systemu i która nabyła oraz nie straciła mocy obowiązującej. Kryteria określone przez pojęcie obowiązywania systemowego tworzą regułę uznania, która ma zawierać względnie jednoznaczne przesłanki rozstrzygania kwestii walidacyjnych. Warto jednak zwrócić uwagę, że w koncepcji H.L.A. Harta reguła uznania jest swojego rodzaju stałą praktyką uznawania norm za obowiązujące (rozstrzygania kwestii walidacyjnych) - stanowi pewien fakt społeczny ${ }^{36}$. Można powiedzieć, że w koncepcji Harta reguła uznania obowiązuje w sensie faktycznym, czyli jest wiążąca, bo stosowana w praktyce ${ }^{37}$. Natomiast w koncepcji J. Wróblewskiego reguła uznania, przynajmniej w swej podstawowej części (kryterium a) obowiązuje w sensie tetycznym — w następstwie aktu stanowienia. Inaczej mówiąc, podstawowy element reguły uznania, jaki tworzą normy kompetencji prawodawczej i procedury prawodawczej (element a), obowiązują na mocy aktu stanowienia przez prawodawcę. A więc to prawodawca, a nie praktyka społeczna określa kryteria decydujące o uznaniu normy za obowiązującą, to znaczy należącą do systemu prawa. Warto zwrócić uwagę, że w teorii prawa J. Wróblewskiego, ten podstawowy element reguły uznania tworzony przez normy kompetencji i procedury prawodawczej, decyduje o tożsamości systemu prawa. Dopóki reguły te są zachowane, dopóty system zachowuje swą tożsamość i nie można mówić o rewolucyjnej zmianie systemu prawa, przynajmniej w płaszczyźnie legalności ${ }^{38}$.

35 J. Wróblewski, Rozumienie..., s. 11; por. też, W. Lang, J. Wróblewski, S. Zawadzki, op. cit., s. 390.

36 H.L.A. Hart, Pojęcie prawa, Warszawa 1998, s. 140 n.

37 J. Woleński, Obowiązywanie prawne w ujęciu H.L.A. Harta, „Zeszyty Naukowe Uniwersytetu Jagiellońskiego, Prace Prawnicze" 1971, z. 51, passim.

38 J. Wróblewski, Zmiany prawa, rewolucja a zmiany spoleczne, [w:] Prawo i prawoznawstwo wobec zmian społecznych, red. H. Rot, Wrocław 1990, passim. 
Kryteria obowiązywania systemowego (a), (c) i (d) wyznaczają system LSLE (system norm legitymujących się uzasadnieniem tetycznym, tzn. będących wynikiem aktów stanowienia przez prawodawcę). Z kolei dodanie kryterium (b) określa system LSFC (system obejmujący obok norm stanowionych również ich formalne konsekwencje). W teorii wykładni J. Wróblewskiego, system LSFC tworzy pojęcie prawa obowiązującego ${ }^{39}$. Cechą wyróżniającą tak pojmowanego „prawa obowiązującego” jest nie tylko „zupełność obowiązywania”, lecz także zachowanie monopolu prawodawcy na określanie co jest prawem obowiązującym. Warto bowiem zwrócić uwagę, że tak rozumiane „prawo obowiązujące” zakłada monopol prawodawcy zarówno na: a) określanie kryteriów obowiązywania prawa, jak i b) podejmowanie działań prawotwórczych zgodnych z określonymi kryteriami tworzącymi regułę uznania. Oznacza to wyłączenie poza zakres prawa obowiązującego reguł tworzących system LSIC (system obejmujący konsekwencje interpretacyjne norm stanowionych) LSOP (prawo operatywne obejmujące reguły obowiązujące $\mathrm{w}$ sensie faktycznym) LSPP (system obejmujący reguły obowiązujące w sensie faktycznym $i$ aksjologicznym). Włączenie do zakresu prawa obowiązującego reguł określonych przez pojęcie systemu LSIC,LSOP, LSPP oznaczałoby pozbawienie prawodawcy monopolu na decydowanie o tym, co jest, a co nie jest prawem obowiązującym, poprzez uznanie, że kryteria obowiązywania prawa mogą być określane $\mathrm{w}$ decyzjach stosowania prawa. Takie rozwiązanie jest dla Wróblewskiego nie do przyjęcia ze względów ideologicznych. Akceptowana przez niego ideologia praworządnej i racjonalnej decyzji sądowej zakłada radykalne oddzielenie tworzenia i stosowania prawa. Zgodna $\mathrm{z}$ tą ideologią jest dyrektywalna koncepcja systemu prawa, w której kryteria obowiązywania określają reguły systemu. Decyzyjna koncepcja systemu, gdzie kryteria obowiązywania są określane w decyzjach podmiotów stosujących prawo, jest nie do pogodzenia z postulatem legalności i praworządności stosowania prawa. Dodatkowo, w przypadku koncepcji LSIC oraz LSPP za odrzuceniem przemawiają również względy operacyjne, to znaczy niemożność określenia normy zamykającej system wskazującej jednoznaczne kryteria obowiązywania norm w systemie, co skutkuje niemożnością określenia granic systemu prawa. Pojęcie prawa obowiązującego, które obejmuje wyłącznie system LSFC, zakłada wizję systemu prawa jednoznacznie zdeterminowanego przez akty stanowienia prawa dokonane przez prawodawcę. Przy takim pojęciu prawa obowiązującego, prawodawca zachowuje monopol zarówno na określanie reguły uznania, jak i na podejmowanie zgodnych z tą regułą działań prawotwórczych.

Określenie granic prawa obowiązującego wymaga analizy pojęcia systemu LSFC, który obejmuje konsekwencje formalne norm ustanowionych tworzących LSLE. Obejmują one te logiczne (dedukcyjne, L-konsekwencje), a także te określone na podstawie reguł rozumowania będących ,interpretacją” konkretnych formuł

39 J. Wróblewski, Rozumienie..., s. 16. 
rachunku logicznego, na przykład a fortiori, wnioskowanie z celu na środki, exceptiones non sunt extendendae. Określone na podstawie tych reguł rozumowania konsekwencje mają charakter quasi-logiczny, ponieważ są wynikiem „odpowiedniego” zastosowania reguł logiki do wypowiedzi normatywnych (QL-konsekwencje). Do kategorii konsekwencji formalnych mogą być zaliczone te określone w wyniku rozumowania analogia legis i a contrario, ale tylko wówczas, gdy ich zastosowanie jest uregulowane prawnie, ponieważ tylko wtedy wynik tych rozumowań może być uznany za konsekwencje systemowe norm stanowionych (S-konsekwencje) ${ }^{40}$.

Przykładowo, prawny zakaz analogii legis jest równoznaczny z nakazem a contrario, wówczas wynik takiego wnioskowania prowadzi do określenia S-konsekwencji obowiązującej normy. Jeżeli natomiast zastosowanie analogii legis lub a contrario nie jest uregulowane prawnie, wówczas ich zastosowanie oparte jest na ocenach, to znaczy stanowi kwestię niezdeterminowanego przez prawodawcę wyboru interpretatora, co powoduje, że określone na tej podstawie konsekwencje norm mają charakter konsekwencji pozornych (P-konsekwencje), lub w innej wersji, konsekwencji domniemanych (D-konsekwencje). Wówczas wyniki zastosowania tych rozumowań nie mają charakteru systemowego (formalnego) i nie mogą być uznane za element prawa obowiązującego ${ }^{41}$.

Jak z tego wynika, w skład systemu prawa LSFC wchodzą tylko konsekwencje typu (L), (QL), oraz (S) — konsekwencje, które dają się określić albo na podstawie reguł logiki (L-konsekwencje), albo na podstawie „odpowiedniego” zastosowania reguł logiki (QL-konsekwencje), bądź na podstawie reguł systemu prawa (S-konsekwencje). Jeżeli natomiast uznanie za konsekwencję norm obowiązujących jest kwestią ocenną i opiera się na uznaniu interpretatora, to wówczas taka konsekwencja nabiera charakteru „pozornego” lub „domniemanego” i nie może być zaliczona do systemu prawa obowiązującego ${ }^{42}$. Warto podkreślić, że sposobem określenia należących do systemu konsekwencji formalnych nie jest analogia iuris, którą J. Wróblewski sprowadza do nakazu rozstrzygania wszelkich nieprzewidzianych wypadków na podstawie „całokształtu przepisów obowiązujących”43. Jego zdaniem, w takim ujęciu dyrektywa ta nie daje sprecyzowanych przesłanek rozstrzygnięcia w postaci określonej normy czy też grupy norm. W innym ujęciu, analogia iuris jest: „,nadaniem prawnych konsekwencji faktom, które według norm zawartych w prawie obowiązującym i ich obowiązujących konsekwencji nie miały takich konsekwencji" ${ }^{4}$. Zdaniem Wróblewskiego, podmiot dokonujący analogii iuris zmienia pozycję ze stosującego prawo na tworzący je ${ }^{45}$. Nawet

40 J. Wróblewski, Zagadnienia..., s. 392 n.; por. też K. Opałek, J. Wróblewski, op. cit., s. $80-87$.

41 J. Wróblewski, Zagadnienia..., s. 86-87.

42 Ibidem, s. 308.

43 Ibidem, s. 305-306.

44 Ibidem, s. 311-314.

45 Ibidem, s. 31. 
w przypadku gdy stosowanie analogii iuris jest prawnie nakazane, określone na tej podstawie konsekwencje tworzą domniemane (pozorne) konsekwencje norm obowiązujących $^{46}$. Jak z tego wynika, powodem odrzucenia analogii iuris jako rozumowania określającego obowiązujące konsekwencje norm jest z jednej strony jej prawotwórczy charakter, $\mathrm{z}$ drugiej zaś duża dowolność w zakresie określenia przesłanek tego rozumowania. Wydaje się, że zachodzi ścisły związek tych powodów odrzucenia analogii iuris jako rozumowania pozwalającego na określenie obowiązujących konsekwencji norm. Dzieje się tak, ponieważ dowolność (ocenny charakter) działań interpretatora w zakresie określenia przesłanek rozumowania prowadzi do nadania mu charakteru prawotwórczego. W każdym razie, nieokreśloność przesłanek wyklucza możliwość uznania wyników analogii iuris za QL-konsekwencje, z kolei nawet wówczas, gdy jej zastosowanie byłoby prawnie nakazane, ocenny charakter rozumowania przesądza o uznaniu jego konsekwencji za pozorne (domniemane).

Warto zwrócić uwagę, że w takiej interpretacji konsekwencje formalne obejmują dwie kategorie: (a) określone przez reguły logicznego myślenia — reguły dedukcyjne, i ich „odpowiedniki” normatywne — zastosowane do wypowiedzi normatywnych, (b) określone przez reguły (normy) systemu prawa. W obu przypadkach, poziom zdeterminowania tych konsekwencji jest bardzo wysoki, w tym sensie, że ich określenie nie stanowi wyniku jakichś mniej lub bardziej swobodnych przypuszczeń (domniemań) interpretatora. $\mathrm{Z}$ pewnym uproszczeniem można powiedzieć, że zarówno w pierwszym, jak i drugim przypadku są to konsekwencje zdeterminowane przez prawodawcę pośrednio (L i QL-konsekwencje) oraz bezpośrednio (S-konsekwencje). Inaczej mówiąc, F-konsekwencje, które tworzą LSFC i wchodzą w skład prawa obowiązującego, to konsekwencje, których uznanie jest koniecznością albo logiczną (określoną przez reguły myślenia, które funkcjonują jako dedukcyjne czy quasi-dedukcyjne reguły języka prawnego), albo normatywną (zdeterminowaną przez normy systemu prawa określające warunki zastosowania analogii legis i a contrario). Natomiast tam, gdzie brakuje determinacji logicznej lub normatywnej, konsekwencje mają charakter pozorny lub domniemany i nie są elementem prawa obowiązującego. Dotyczy to analogii iuris ze względu na jej prawotwórczy charakter, oraz analogii legis i a contrario, wówczas gdy zastosowanie tych rozumowań nie jest zdeterminowane normatywnie i o tym, czy dany typ rozumowania zostanie przeprowadzony, decydują oceny interpretatora. Warto ten fakt wyeksponować, ponieważ na gruncie omawianej teorii wykładni, model LSFC, czyli prawo stanowione oraz jego konsekwencje formalne, łącznie tworzą pojęcie prawa obowiązującego będącego przedmiotem interpretacji ${ }^{47}$.

Jak wspominano, podstawowa dyrektywa wykładni systemowej zawiera nakaz przeprowadzenia wykładni w sposób pozwalający na uniknięcie sprzeczności

\footnotetext{
46 Ibidem.

47 J. Wróblewski, Rozumienie..., s. 16.
} 
technicznych w systemie prawa. W omawianej teorii wykładni sprzeczność norm jest rozumiana jako sytuacja, w której zrealizowanie jednej normy N1 wyklucza możliwość zrealizowania drugiej normy N2 ${ }^{48}$. Te sprzeczności mogą mieć charakter abstrakcyjny (wówczas są identyfikowane już na poziomie analizy językowej, np. zachowanie w N1 jest określone jako negacja zachowania w N2) lub konkretny (sytuacja tzw. zbiegu norm w konkretnym przypadku wykluczająca możliwość jednoczesnej realizacji N1 i N2 $)^{49}$. Tak rozumiana sprzeczność ma charakter techniczny, wówczas gdy nie jest przez ustawodawcę zamierzona i może być uznana za efekt wadliwej techniki legislacyjnej. Inaczej mówiąc, nie jest to sprzeczność występująca w głębokiej strukturze prawa (poziom celowych działań prawodawcy), lecz w jego warstwie powierzchniowej (poziom sformułowania norm) ${ }^{50}$. Sprzeczności techniczne Wróblewski uznaje za nieuchronnie związane z rozwojem prawa. Sprzeczności te powstają wówczas gdy w związku z dynamicznym rozwojem stosunków społecznych „prawo nie nadąża za życiem” ${ }^{51}$. Postęp w obszarze techniki legislacyjnej może prowadzić do redukcji tego typu sprzeczności. Autor ów z jednej strony wskazuje na nieuchronność wad techniki legislacyjnej, z drugiej - wyraża przekonanie co do nieuchronności postępu w tym zakresie ${ }^{52}$.

$\mathrm{Na}$ gruncie omawianej teorii wykładni, oryginalnym rozstrzygnięciem w zakresie pojmowania luk w systemie prawa jest uznanie luk technicznych za szczególną postać sprzeczności technicznych. Luka techniczna jest postrzegana jako sytuacja, gdy ,reguły wyznaczające pozytywne konsekwencje faktu nie są kompletne w tym sensie, że nie regulują jakiegoś elementu instytucji, bez którego orzeczenie konsekwencji pozytywnych nie jest możliwe"53. Wróblewski interpretuje tę sytuację jako sprzeczność techniczną pomiędzy nakazem orzeczenia konsekwencji pozytywnych wynikającą z generalnego nakazu rozstrzygnięcia a zakazem orzeczenia tych konsekwencji wynikającym z braku podstawy prawnej. Zastosowanie w takiej sytuacji analogii legis może prowadzić do określenia S-konsekwencji (konsekwencje systemowe wchodzące w skład systemu prawa) lub D-konsekwencji (konsekwencje domniemane nie należące do systemu prawa), W zależności od poziomu determinacji normatywnej posłużenia się tym rozumowaniem ${ }^{54}$.

W kwestii uznawania konsekwencji analogii legis za obowiązujące normy, stanowisko Wróblewskiego jest ambiwalentne. W pierwotnej wersji, gdy z uwagi na brak determinacji normatywnej, zastosowanie tego rozumowania prowadzi

48 J. Wróblewski, Zagadnienia..., s. 283 n.

49 W. Lang, J. Wróblewski, S. Zawadzki, op. cit., s. 400-401.

50 J. Wróblewski, Zagadnienie niesprzeczności i zupetności systemu prawa, „Zeszyty Naukowe Uniwersytetu Łódzkiego, Nauki Humanistyczno-Społeczne, Seria I", Łódź 1958, z. 9, s. 5-6.

51 J. Wróblewski, Zagadnienia..., s. 284

52 Ibidem.

53 W. Lang, J. Wróblewski, S. Zawadzki, op. cit., s. 407.

54 J. Wróblewski, Zagadnienia..., s. 314. 
do konsekwencji domniemanych (opartych na przypuszczeniach interpretatora), wówczas konsekwencje te nie są uznawane za obowiązujące normy stanowiące część systemu prawa ${ }^{55}$. W wersji późniejszej (złagodzonej) autor ów uznaje, że gdy rozumowanie (w tym analogia legis) z uwagi na brak determinacji logicznej lub normatywnej, prowadzi do konsekwencji pozornych (domniemanych), wówczas zasadność jego przeprowadzenia powinna być mierzona zasadnością ocen, które decydują o jego zastosowaniu ${ }^{56}$. Oznaczałoby to, że można uznać konsekwencje domniemane za określające obowiązujące normy — należące do systemu prawa LSFC, jeżeli uzasadniają to oceny przyjęte przy formułowaniu tych konsekwencji. Konsekwencje analogii legis mogłyby być zatem uznane za F-konsekwencje, nawet wówczas, gdy z uwagi na brak determinacji normatywnej efekty zastosowanie tego wnioskowania nie mogą być uznane za S-konsekwencje. Taki pogląd zdaje się potwierdzać teza, że na gruncie postulowanej ideologii praworządnej i racjonalnej decyzji sądowej, dopuszczalne jest zarówno oceniające stwierdzanie sprzeczności technicznych, jak i oceniające ich rozstrzyganie w drodze analogii legis ${ }^{57}$. W konsekwencji oznaczałoby to, że o zaliczeniu konsekwencji norm do systemu prawa jako F-konsekwencji, decyduje z jednej strony konieczność logiczna i normatywna (L, QL, S-konsekwencje), z drugiej zaś zasadność zastosowanych ocen. Ta druga sytuacja miałaby miejsce wówczas, gdy zastosowanie analogii legis, z uwagi na brak determinacji normatywnej nie może być uznane za prowadzące do określenia S-konsekwencji, a mimo to istnieją silne racje aksjologiczne uzasadniające przeprowadzenie takiego rozumowania. Warto dodać, że o zasadności ocen należy decydować na gruncie postulowanej przez Wróblewskiego ideologii praworządnej i racjonalnej decyzji sądowej, która zakłada pełną identyfikację interpretatora $\mathrm{z}$ systemem wartości wewnętrznych prawa ludowego, określonych przez ideologię socjalistyczną. Trzeba także zwrócić uwagę, że ideologia racjonalnej i praworządnej decyzji sądowej wyklucza swobodę interpretatora w zakresie dokonywania wyborów oceniających. Integralną częścią tej ideologii jest postulat pełnej internalizacji przez interpretatora systemu wartości wewnętrznych prawa ludowego. Warto również podkreślić, że w ujęciu J. Wróblewskiego system wartości wewnętrznych prawa ludowego charakteryzuje wysoki poziom spójności aksjologicznej, co powoduje, że system ten może być uznany za definiujący powszechnie akceptowaną formę życia. Przy założeniu, że spójny system wartości wewnętrznych prawa ludowego jest określany przez ideologię socjalistyczną, wówczas definiowaną przez ten system formą życia może być tylko wolne od alienacji społeczeństwo komunistyczne. Dodajmy, że w ujęciu Wróblewskiego, założenie o istnieniu powszechnie akceptowanej formy życia, czy też powszechnie akceptowanego systemu wartości, którego obowiązkowa in-

\footnotetext{
55 Ibidem, s. 282 n.

56 K. Opałek, J. Wróblewski, op. cit., s. 87.

57 W. Lang, J. Wróblewski, S. Zawadzki, op. cit., s. 408.
} 
ternalizacja określać ma wybory aksjologiczne interpretatora, jest uznawane za podstawową aksjologiczną presupozycję prawniczych rozumowań interpretacyjnych $^{58}$.

$\mathrm{Na}$ gruncie omawianej teorii wykładni fundamentalnym założeniem decydującym o obrazie systemu prawa ludowego jest uznanie sprzeczności technicznych za sprzeczności pozorne. Pozorność tych sprzeczności zakłada że: (a) są to sprzeczności niezamierzone przez prawodawcę i w tym sensie przypadkowe, (b) ich występowanie jest związane $z$ dynamicznym rozwojem prawa i nieuchronnych w tym kontekście błędów techniki legislacyjnej, (c) nie są to sprzeczności prawa, lecz sformułowania prawa, to znaczy nie są to występujące w strukturze głębokiej prawa zamierzone sprzeczności norm, lecz tkwiące w strukturze powierzchniowej prawa przypadkowe sprzeczności na poziomie sformułowania norm, (d) są to sprzeczności prima facie, które znikają jeśli dostatecznie wnikliwie ustali się znaczenie norm w drodze interpretacji, lub jeśli zastosuje się reguły kolizyjne ${ }^{59}$. Identyfikacja tak pojmowanych sprzeczności technicznych opiera się na założeniu, że są one wynikiem błędów na poziomie techniki prawotwórczej. W związku z tym mogą być usuwane na drodze zabiegów interpretacyjnych i wówczas takie działanie nie nosi znamion działalności prawotwórczej. Co więcej, można zasadnie twierdzić, że takie działanie jest zgodne z intencjami twórcy niedoskonałego tekstu prawnego, w którym prawodawca po prostu źle się wyraził. Takie ujęcie działań interpretacyjnych związanych z występowaniem sprzeczności technicznych jest konsekwencją ich postrzegania jako sprzeczności prima facie występujących na poziomie sformułowania prawa. Istotne, że usuwając sprzeczności techniczne, interpretator nie wchodzi w kompetencje prawodawcy, pozostając $\mathrm{w}$ granicach określonych rolą interpretatora. Z założenia zatem, usuwanie sprzeczności technicznych jest interpretacją prawa, a nie jego tworzeniem.

J. Wróblewski przeciwstawia pozorne sprzeczności techniczne realnym sprzecznościom politycznym. Sprzeczności polityczne w systemie prawa mają charakter realny, ponieważ są następstwem sprzeczności (konfliktów) klasowych. Ich istnienie jest zamierzone jako rezultat gry sił politycznych. Odwołując się do prac klasyków marksizmu, autor ów wskazuje jako przykład sprzeczności politycznych sytuację, w której będące wynikiem kompromisu politycznego normy konstytucyjne przyznają pewne uprawnienia następnie ograniczane przez normy niższego rzędu. To sytuacja fasadowości (programowości) norm konstytucyjnych, które, przyznając pewne uprawnienia, nie są realizowane ze względu na ograniczające lub wręcz wykluczające regulacje niższego szczebla. Za szczególnie ra-

58 J. Wróblewski, Presupozycje rozumowania prawniczego, „Studia Prawno-Ekonomiczne” XXXVII, 1986, s. 12, 18-19; por. też idem, Rozumienie..., s. 108 n., gdzie Wróblewski formułuje postulat racjonalności materialnej decyzji interpretacyjnej rozumiany jako zgodność decyzji interpretacyjnej z powszechnie akceptowaną formą życia określoną przez wartości wewnętrzne prawa; por. też idem, Poziomy uzasadnienia decyzji prawnej, „Studia Prawno-Ekonomiczne” XL, 1988, s. 29 n.

59 J. Wróblewski, Zagadnienie niesprzeczności..., passim. 
dykalną postać takich sprzeczności, autor ów uznaje swoistą lukę w prawie (tzw. sprzeczność realizacyjna), która polega na tym, że prawodawca celowo nie wydaje norm koniecznych do realizacji norm programowych ${ }^{60}$. Realny charakter sprzeczności politycznych powoduje, że nie mogą być one usunięte w procesie wykładni, a tylko w wyniku działalności prawodawcy. Przy założeniu, że sprzeczności te są charakterystyczne dla społeczeństw klasowych, ich występowanie w systemie prawa ludowego staje się niemożliwe. Wróblewski stwierdza wyraźnie: „Założenia funkcjonowania socjalistycznego systemu politycznego nie pozwalają na powstawanie tego typu sprzeczności" 61.

Warto szczególnie podkreślić, że stanowiąca założenie omawianej teorii wykładni konstrukcja systemu prawa ludowego LSFC, jest nie tylko konstrukcją teoretyczną wykluczającą istnienie realnych sprzeczności w systemie prawa, lecz także eliminującą istniejące w nim luki w systemie prawa. System prawa ludowego jest zatem nie tylko realnie niesprzeczny, lecz także realnie zupełny. W omawianej teorii wykładni, efekt realnej zupełności systemu prawa ludowego osiąga się dzięki ujęciu niezupełności regulacji prawnej w kategoriach pozornej sprzeczności technicznej eliminowanej za pomocą analogii legis, lub tak jak typowe sprzeczności techniczne, za pomocą zabiegów interpretacyjnych. W takim ujęciu, eliminacji luki technicznej, nie jest zabiegiem prawotwórczym, czyli noszącym znamiona kreacji nowości normatywnej uzupełnianiem braków regulacji prawnej, lecz tylko usuwaniem pozornych niedoskonałości występujących na poziomie sformułowania przepisów prawnych. Ujęcie luki technicznej jako technicznej sprzeczności oznacza, że nie jest to sytuacja realnego braku regulacji prawnej, którą można usunąć wyłącznie poprzez zabiegi prawotwórcze, lecz tylko sytuacja polegająca na niedoskonałym sformułowaniu regulacji już istniejących, którą można usunąć poprzez niemające charakteru prawotwórczego działania interpretacyjne.

Zdaniem autora niniejszego opracowania, wpływ założeń ideologicznych na przyjętą koncepcję realnej niesprzeczności i zupełności systemu prawa jest ewidentny. Ideologia racjonalnej i praworządnej decyzji sądowej opiera się na radykalnej opozycji tworzenia i stosowania prawa, co skutkuje równie radykalnym zanegowaniem prawotwórstwa sądowego ${ }^{62}$. Fundamentalnym założeniem tej ideologii jest uznanie niekwestionowanego monopolu prawodawcy na tworzenie prawa, co stanowi konsekwencję dokonanych na poziomie filozoficznym rozstrzygnięć dotyczących ontologii prawa ludowego. Zgodnie z filozoficznymi rozstrzygnięciami marksizmu, prawo ludowe to narzędzie globalnej przebudowy społecznej polegającej na tworzeniu bytu wyższego rzędu (wolne od alienacji społeczeństwo komunistyczne). Z kolei, zgodnie z epistemologicznymi założeniami marksizmu, poznanie bytu wyższego rzędu jest dostępne wyłącznie uprzy-

60 J. Wróblewski, Zagadnienia..., s. 286.

61 K. Opałek, J. Wróblewski, op. cit., s. 99.

62 J. Wróblewski, Sądowe stosowanie..., passim. 
wilejowanym poznawczo politycznym reprezentantom klasy postępowej (klasy wstępującej, która reprezentuje obiektywny proces postępu dziejowego). A zatem, to uprzywilejowanie poznawcze predestynuje do występowania w roli ludowego prawodawcy. W konsekwencji, nikt inny (w szczególności stosujący prawo interpretator) nie jest legitymowany do podejmowania działań prawotwórczych, które mogłyby naruszać monopol uprzywilejowanego epistemologicznie prawodawcy. Proponowane przez Autora konstrukcje teoretyczne niesprzeczności oraz zupełności systemu prawa ludowego wykluczające prawotwórstwo sądowe, należy zatem uznać za konsekwencje przyjęcia powyższych rozstrzygnięć filozoficznych w charakterze pierwotnych poznawczo przesłanek działalności teoretycznej, to znaczy działalności poznawczej realizowanej na poziomie teorii prawa.

W kwestii roli zasad systemu prawa w procesie ustalania znaczenia tekstu prawnego, stanowisko Autora jest ambiwalentne. W pierwotnej wersji zakłada on subsydiarną rolę zasad - przyjmuje stanowisko, zgodnie z którym interpretator może odwołać się do zasad tylko wówczas, gdy zastosowanie innych dyrektyw językowych nie prowadzi do jednoznacznych wyników. Inaczej mówiąc, pomocniczy charakter zasad polega na tym, że służą one rozstrzyganiu konfliktów interpretacyjnych powstałych w związku z zastosowaniem innych dyrektyw wykładni (np. dyrektyw językowych). Przejawem takiego stanowiska jest dyrektywa: „Jeżeli na gruncie dyrektyw językowych istnieją wątpliwości co do znaczenia normy prawnej, to należy wybrać takie rozstrzygnięcie, które jest zgodne z zasadami części systemu prawa i systemu prawa, do którego interpretowana norma należy"63. W wersji późniejszej, którą można uznać za bardziej reprezentatywną, zasady odgrywają rolę samoistną w procesie ustalania znaczenia normy. Przejawem takiego stanowiska mogą być dyrektywy: „W razie sprzeczności normy z zasadą systemu prawa, należy tak ustalić znaczenie interpretowanej normy, by nie była ona $\mathrm{z}$ tą zasadą sprzeczna"64 lub też: „Należy przypisywać interpretowanej regule prawa znaczenie, przy którym jest ona najbardziej koherentna z uznaną zasadą prawa" ${ }^{65}$.

$\mathrm{W}$ omawianej teorii wykładni, podstawowe znaczenie dla pojmowania zasad systemu prawa ma odrzucenie stanowisk, które Autor określa mianem „nihilizmu prawnego". W jego ujęciu jest nim każde stanowisko, które zakłada inny sposób istnienia zasad jak tylko w następstwie aktu stanowienia przez prawodawcę. W konsekwencji, ,nihilizmem prawnym” jest zarówno prawnonaturalne pojmowanie zasad (wyższy porząadek normatywny identyfikowany na podstawie kryteriów aksjologicznych), jak i ujęcia realistyczne (zasady prawa jako fakty społeczne) ${ }^{66}$. Mówiąc krótko, o tym, co jest zasadą prawa, decyduje wyłącznie prawodawca w akcie stanowienia. W konsekwencji Wróblewski dokonuje podsta-

63 J. Wróblewski, Zagadnienia..., s. 281.

64 W. Lang, J. Wróblewski, S. Zawadzki, op. cit., s. 445; por. też, K. Opałek, J. Wróblewski, op. cit., s. 250.

65 J. Wróblewski, Rozumienie..., s. 83.

66 J. Wróblewski, Zagadnienia..., s. 258; por. też, K. Opałek, J. Wróblewski, op. cit., s. 116-120. 
wowego rozróżnienia pojęciowo-terminologicznego, oddzielając zasady systemu prawa (zasady reguły) oraz postulaty systemu prawa (zasady postulaty) ${ }^{67}$. Zasady reguły to normy obowiązujące lub też ich konsekwencje formalne (logiczne), które ze względu na swoją treść mają znaczenie podstawowe dla całego systemu prawa lub jego części. Zasady reguły są częścią systemu prawa obowiązującego - obowiązują tetycznie, zgodnie z kryteriami obowiązywania systemowego i jako takie są elementem systemu LSFC obejmującego normy stanowione (system LSLE) oraz ich konsekwencje formalne (L lub QL-konsekwencje) lub systemowe (S- konsekwencje). Z kolei zasady postulaty należą do systemu w przypadku zaakceptowania szerokiej i decyzyjnej koncepcji systemu LSPP, którego elementami są oprócz reguł stanowionych także principles, policies and other standards, a więc reguły obowiązujące $\mathrm{w}$ sensie aksjologicznym i/lub faktycznym, czyli niebędące wynikiem aktu stanowienia przez prawodawcę ${ }^{68}$. Koncepcja systemu LSPP jest decyzyjną koncepcją systemu, ponieważ o uznaniu normy za obowiązującą przesądzają decyzje organów stosujących prawo (interpretatorów), które opierają się na kryteriach aksjologicznych i/lub faktycznych. Tak pojmowaną koncepcję systemu LSPP Wróblewski zdecydowanie odrzuca i wskazuje, że zakłada ona przynależność do systemu reguł, które nie spełniają reguły uznania określonej przez pojęcie obowiązywania systemowego normy. Autor ten jednoznacznie opowiada się za wąską i dyrektywalną koncepcją systemu prawa (LSFC), w której reguła uznania nakazuje uznawać za obowiązujące tylko reguły stanowione przez prawodawcę oraz ich formalne konsekwencje, uzasadniając takie stanowisko koniecznością odróżniania lex lata i lex ferenda, to znaczy prawa obowiązującego i prawa postulowanego ${ }^{69}$. Koncepcja systemu LSPP, w ujęciu R. Dworkina jest pomyślana jako likwidująca swobodne uznanie w przypadku braku reguły stanowionej, ponieważ w takim przypadku sędzia ma obowiązek zastosować principles, policies and other standards, które legitymują się odpowiednim uzasadnieniem aksjologicznym i „wsparciem instytucjonalnym” w postaci uwzględniania w dotychczasowej praktyce orzeczniczej. Autor zarzuca koncepcji systemu LSPP nieokreśloność granic systemu oraz pozorność przezwyciężenia luzów decyzyjnych w procesie stosowania prawa $\mathrm{z}$ uwagi na nieostre (ocenne) kryteria uznawania określonych standardów za obowiązujące w sensie faktycznym i aksjologicznym przez organy stosujące prawo ${ }^{70}$. Trzeba jednak wyraźnie podkreślić, że tym, co przesądza o odrzuceniu koncepcji systemu LSPP, jest fakt, że koncepcja systemu LSPP zakłada przełamanie monopolu na decydowanie o tym, co jest, a co nie jest prawem obowiązującym, który zgodnie z przyjętymi w omawianej teorii założeniami filozoficznymi marksizmu, przysługuje niepodzielnie uprzywilejowanemu

67 W. Lang, J. Wróblewski, S. Zawadzki, op. cit., s. 398-400.

68 J. Wróblewski, Rozumienie..., s. 14.

69 Ibidem; por. też, W. Lang, J. Wróblewski, S. Zawadzki, op. cit., s. 400; por. też, J. Wróblewski, Decyzja sądowa..., s. 17-20, oraz s. 22-23.

70 J. Wróblewski, Rozumienie..., s. 14. 
poznawczo prawodawcy reprezentującemu klasę postępową. Dodajmy, że przyjęta koncepcja prawa obowiązującego (system LSFC) zakłada monopol prawodawcy na decydowanie o prawie obowiązującym i w tym sensie jest zgodna $\mathrm{z}$ wizją prawa określoną przez pierwotne poznawczo założenia filozofii marksistowskiej. Warto przypomnieć, że zgodnie z tymi założeniami, tylko awangarda klasy postępowej jest legitymowana epistemicznie do działań prawotwórczych, to znaczy do występowania $\mathrm{w}$ roli prawodawcy, ponieważ dysponuje wyróżnioną wiedzą na temat wyższej formy społecznego istnienia (komunizm), która ma być tworzona za pomocą prawa ludowego.

Konsekwencją wierności przyjętym założeniom filozoficznym jest odnoszenie dyrektywy wykładni systemowej nakazującej koherencję znaczenia normy z zasadami prawa, wyłącznie do ,zasad regul” — norm zasadniczych obowiązujących na mocy aktu stanowienia lub wynikających z tych norm z logiczną koniecznością (LSFC). Stąd kolejną dyrektywą wykładni systemowej jest ta: „Jeżeli powołuje się zasadę systemu (czy jego części) to należy ją skonkretyzować przez wskazanie konkretnego przepisu czy ich grupy zawierającej daną zasadę, lub przepisu czy ich grupy, z której zasada ta w sposób niewątpliwy wynika (L lub QL-konsekwencje)" "71.

Wierność przyjętym założeniom filozoficznym powoduje także, że na gruncie omawianej teorii wykładni, postulaty systemu prawa (principles, policies and other standards) zalicza się do pozaprawnego kontekstu funkcjonalnego, który kreują ,pozaprawne oceny i reguły społeczne”, i jako takie są uwzględniane w ramach wykładni funkcjonalnej. Standardy te tworzą dynamiczną kategorię reguł, takich jak na przykład zasady współżycia społecznego, przy czym dynamika ta jest często stymulowana przez prawodawcę ${ }^{72}$. Na gruncie omawianej teorii wykładni, to prawo stymuluje rozwój ocen i norm pozaprawnych, ponieważ mają być one zgodne $\mathrm{z}$ celami i zadaniami państwa ludowego. Jednym $\mathrm{z}$ tych zadań jest właśnie tworzenie wyższej moralności socjalistycznej (komunistycznej).

Jest charakterystyczne, że za jedyne powszechne dyrektywy związane z kontekstem funkcjonalnym Wróblewski uznaje te, które wiążą się z dążeniem do zachowania spójności aksjologicznej systemu prawa ${ }^{73}$. W dyrektywach wykładni funkcjonalnej nakaz zachowania spójności aksjologicznej systemu prawa może być wyrażony w postaci hipotetycznej lub kategorycznej. W pierwszym przypadku dyrektywa interpretacyjna ma postać następującą: „Jeżeli uwzględnia się cele, wartości i reguły pozaprawne w ustalaniu znaczenia interpretowanej reguły prawnej, to winny być one jednakowo uwzględniane w stosunku do wszystkich reguł, z których składa się instytucja, do jakiej interpretowana reguła należy"74. Warto zwrócić uwagę na występujące w tej dyrektywie ograniczenie nakazu spójności

71 J. Wróblewski, Zagadnienia..., s. 278.

72 Ibidem, s. 392.

73 J. Wróblewski, Rozumienie..., s. 84.

74 Ibidem. 
aksjologicznej do granic instytucji, do której należy interpretowana norma. Ograniczenia tego nie ma wówczas, gdy dyrektywa przybiera postać kategoryczną: „Interpretowanej regule należy przypisywać znaczenie, przy którym jest ona najbardziej zgodna z uznanymi ocenami systemu aksjologicznego lub też ocenami uznanego systemu aksjologicznego"75. Jak się wydaje, przyjęcie formuły hipotetycznej w pierwszym przypadku i kategorycznej w drugim nie jest przypadkowe. Warto bowiem zwrócić uwagę, że w pierwszym przypadku mowa o „pozaprawnych ocenach i regułach społecznych", a więc takich, które nie są ocenami i wartościami wewnętrznymi prawa ludowego — wówczas interpretator może je uwzględnić bądź nie. W drugim przypadku mowa o , uznanym systemie aksjologicznym”, bez wskazania, czy chodzi tu o system wartości wewnętrznych prawa, czy też o pozaprawne standardy. Warto przypomnieć, że na gruncie omawianej teorii wykładni, założenie o istnieniu powszechnie akceptowanego systemu wartości obok założenia o istnieniu powszechnych dyrektyw interpretacyjnych jest sugerowane jako konieczny element uzasadnienia decyzji interpretacyjnych ${ }^{76}$. Można zatem przyjąć, że „uznany system aksjologiczny” to system wartości definiujący powszechnie akceptowaną formę życia, do której odwołuje się interpretator uzasadniając dokonywane w toku wykładni wybory aksjologiczne. Rzecz jasna, postulat odwołania się interpretatora do „uznanego systemu aksjologicznego”, czy też do powszechnie akceptowanej formy życia, zakłada kulturową relatywizację systemu wartości uzasadniającego decyzję interpretacyjną ${ }^{77}$. Trzeba jednak podkreślić, że akceptowana przez J. Wróblewskiego ideologia praworządnej i racjonalnej decyzji sądowej (interpretacyjnej) formułuje bezwzględny postulat racjonalności materialnej interpretatora. Oznacza to, że zgodnie z postulatami wspomnianej ideologii interpretator nie może uzasadniać dokonywanych wyborów aksjologicznych, odwołując się do dowolnego systemu wartości definiującego jakąś formę życia. Określony przez ideologię praworządnej i racjonalnej decyzji sądowej (interpretacyjnej) postulat racjonalności materialnej interpretatora zakłada, że jedynym systemem wartości, którego uwzględnienie stanowi nieodzowny obowiązek interpretatora, jest system wartości wewnętrznych prawa ludowego określony przez ideologię socjalistyczną. Określa on wyższą formę życia (społeczeństwo komunistyczne) zdefiniowaną przez obiektywne prawa postępu dziejowego ${ }^{78}$. W konsekwencji należy uznać, że na gruncie ideologii praworządnej i racjonalnej decyzji sądowej (interpretacyjnej) jedynym „uznanym systemem aksjologicznym” może być ten wyznaczony przez obiektywne prawa postępu społecznego zidentyfikowane na poziomie pierwotnych poznawczo założeń filozoficznych marksizmu. Należy dodać, że na gruncie ide-

75 Ibidem, s. 85.

76 J. Wróblewski, Presupozycje..., s. 18-19.

77 Ibidem, s. 18.

78 J. Wróblewski, Zagadnienia..., s. 181-182; por. też ibidem, s. 199; por. też W. Lang, J. Wróblewski, S. Zawadzki, op. cit., s. 486; por. też J. Wróblewski, Wartości a decyzja sądowa, s. 87-93. 
ologii praworządnej i racjonalnej decyzji sądowej (interpretacyjnej) „pozaprawne oceny i reguły społeczne", o których mowa w hipotetycznym wariancie dyrektywy funkcjonalnej, mogą być uwzględnione tylko w takim zakresie, w jakim są zgodne z wartościami wewnętrznymi prawa ludowego, których wzięcie pod uwagę jest bezwzględnym obowiązkiem interpretatora. Tę kategoryczną powinność wyraża bezwarunkowa postać dyrektywy nakazującej dążenie do zachowania spójności aksjologicznej systemu prawa w procesie interpretacji.

\section{KONKLUZJE}

Teoria wykładni prawa J. Wróblewskiego reprezentuje postawę filozoficzną polegającą na przyjęciu podstawowych założeń filozoficznych marksizmu, w charakterze pierwotnych poznawczo przesłanek działalności teoretycznej w prawoznawstwie. Używając terminologii tego autora, pomiędzy rzeczoną teorią wykładni a podstawowymi założeniami marksizmu zachodzi zarówno relacja powołania, jak i przyporządkowania. W konsekwencji, sposób pojmowania systemowości prawa w teorii wykładni J. Wróblewskiego jest przesądzony przez przyjęcie pierwotnych poznawczo założeń filozoficznych marksizmu. Jest tak, ponieważ omawiana teoria wykładni to teoria wykładni prawa ludowego, a prawo ludowe stanowi kategorię filozoficzną, w której podstawowe cechy prawa ludowego są określone przez pierwotne poznawczo założenia filozoficzne. Oznacza to, że formułowane przez Wróblewskiego twierdzenia teorii wykładni presuponują istnienie prawa ludowego jako kategorii filozoficznej. Istnienie prawa ludowego jest podstawową presupozycją ontologiczną omawianej teorii wykładni. W tym sensie, twierdzenia teoretyczne stanowią konsekwencje pierwotnych poznawczo założeń filozoficznych. Relacja pierwotności logicznej to relacja presupozycji semantycznej, która zachodzi pomiędzy formułowanymi na poziomie poznania filozoficznego sądami egzystencjalnymi na temat bytu społecznego, jakim jest prawo ludowe, a formułowanymi na poziomie poznania teoretycznoprawnego twierdzeniami o wykładni prawa ludowego. W przypadku omawianej teorii wykładni, założenie systemowości prawa może być zatem rozpatrywane zarówno na poziomie pierwotnych poznawczo założeń filozoficznych, jak również na poziomie poznawczo wtórnych twierdzeń teoretycznoprawnych o prawie i jego wykładni, a także na poziomie określonych przez te twierdzenia dyrektyw interpretacyjnych.

1. Poziom założeń filozoficznych:

a) założenia o rzeczywistości społecznej — rzeczywistość społeczna jest zdeterminowana przez obiektywny proces postępu dziejowego, który polega na przejściu od niższej (byt dotknięty alienacją w społeczeństwach klasowych) do wyższej postaci bytu społecznego (byt wolny od alienacji w bezklasowym społeczeństwie komunistycznym). Ten obiektywny proces dziejowy określa etykę postępu (etykę 
normatywną) wyznaczaną przez postrzeganie wyższej formy bytu społecznego jako najwyższej wartości w systemie wartości klasy postępowej. Obraz świata społecznego w marksizmie jest nie tylko logocentryczny, co zakłada podleganie procesu dziejowego obiektywnym prawidłowościom, lecz także przyjmuje systemowość bytu społecznego, co wyraża kategoria formacji społeczno-ekonomicznej i zakładane przez nią relacje bazy i nadbudowy. Komunizm jako byt przezwyciężający alienację jest wolny od realnych sprzeczności politycznych charakterystycznych dla społeczeństw klasowych. Komunizm jako postać bytu, w której dokonuje się pełne uspołecznienie człowieka, realizuje stan wolności społecznej pojmowanej jako jedność społeczna;

b) założenia o prawie ludowym - prawo ludowe jest narzędziem, którego użycie przez uprzywilejowanego poznawczo prawodawcę ma przyspieszać obiektywny proces dziejowy przechodzenia od niższej do wyższej formy społecznego istnienia. Skuteczność prawa jako narzędzia globalnej przebudowy społecznej implikuje jego systemowe uporządkowanie. W marksizmie instrumentalne pojmowanie prawa przesądza o jego systemowości. W szczególności, system prawa ludowego charakteryzują jedność socjologiczna, teleologiczna, formalna i materialna. Wyróżniona wiedza na temat wyższej formy bytu, jaką dysponuje uprzywilejowany poznawczo prawodawca, uzasadnia jego bezwzględny monopol na tworzenie prawa ludowego. W warunkach wyższej formy społecznego istnienia, prawo ludowe przestaje być formą mediacji sprzecznych interesów klasowych i staje się narzędziem tworzenia społecznej jedności. Określone na poziomie założeń filozoficznych wartości pierwotne, które definiują akceptowaną formę życia (komunizm), zostają zakodowane w prawie ludowym w postaci spójnego systemu wartości wewnętrznych prawa ludowego. Zgodnie z ideologią racjonalnej i praworządnej decyzji sądowej, uwzględnienie tego systemu wartości w procesie wykładni prawa, jest bezwzględnym obowiązkiem interpretatora.

2. Poziom twierdzeń teoretycznych o prawie ludowym i jego wykładni:

a) na poziomie rozstrzygnięć semantycznych, charakterystyczne jest obiektywizujące istnienie normy założenie, że nie jest ona tożsama ze swoim znaczeniem, co powoduje, że zmiana znaczenia w wyniku wykładni nie jest równoznaczna ze zmianą normy (prawa). Norma (prawo) to coś więcej niż znaczenie (wzór zachowania) określane standardowo w wyniku bezpośredniego rozumienia normy, albo wyjątkowo w wyniku pośredniego rozumienia normy, czyli w wyniku wykładni polegającej na stosowaniu dyrektyw interpretacyjnych. Założenie obiektywnego istnienia normy oznacza, że istnieje ona niezależnie od aktów określania jej znaczenia w sposób bezpośredni lub pośredni. Inaczej mówiąc, prawo (norma) istnieje niezależnie od aktów rozumienia tekstów prawnych w sposób bezpośredni lub pośredni, który polega na stosowaniu dyrektyw interpretacyjnych (wykładnia). Prawo jako fakt obiektywny — istniejący niezależnie od interpretatora, nie jest faktem interpretacyjnym (dyskursywnym) określanym przez interpretatora w ak- 
cie interpretacji (dyskursie prawniczym), lecz faktem imperatywnym, który definiowanym przez prawodawcę $\mathrm{w}$ akcie stanowienia;

b) obiektywnym istnieniem charakteryzuje się nie tylko norma, lecz także jej znaczenie w postaci wzoru zachowania. Założenie, że norma ma znaczenie przynajmniej w pewnym stopniu niezależne od interpretatora, jest traktowane jako konieczna i w tym sensie podstawowa presupozycja rozumowań interpretacyjnych. Poziom obiektywności (niezależności od interpretatora) znaczenia normy jest zróżnicowany w zależności od tego, czy znaczenie to da się określić przy zastosowaniu ,powszechnych dyrektyw interpretacyjnych”, czy też interpretator musi dokonać wyboru dyrektyw określonych przez statyczną lub dynamiczną ideologię wykładni. W pierwszym przypadku, poziom ten jest większy, w drugim mniejszy. Powszechne dyrektywy interpretacyjne odwołują się do oczywistych właściwości kontekstu językowego i systemowego normy, i interpretator nie może ich zignorować, z uwagi na fakt ich powszechnej akceptacji. Jeżeli ich zastosowanie jest wystarczające dla określenia znaczenia normy, wówczas jest to tak zwane „rzeczywiste znaczenie normy”. Odstępstwo od tego znaczenia uznaje się za odstępstwo od prawa obowiązującego;

c) podstawową presupozycją rozumowań interpretacyjnych jest nie tylko teza o obiektywnym istnieniu normy i jej znaczenia, lecz także o obiektywnym istnieniu systemu prawa jako uporządkowanego zbioru norm. Założenie systemowości prawa ma zdecydowanie konotację ontologiczną, a nie epistemologiczną - według niego prawo istnieje jako system w wyniku działań prawodawcy, a nie staje się systemem w wyniku działań interpretatora. Teza o systemowości prawa jest zawsze punktem wyjścia działań interpretacyjnych, a nie ich skutkiem. Założenie systemowości prawa to zatem podstawowa presupozycja egzystencjalna — określająca sposób istnienia prawa, przyjmowana $\mathrm{w}$ prawniczych rozumowań interpretacyjnych;

d) omawianą teorię prawa cechuje konsekwentne podkreślanie konieczności rozgraniczenia tworzenia i stosowania prawa, którego częścią jest wykładnia. Stosowanie prawa i jego wykładnia nie może być aktem twórczym, tzn. prowadzącym do kreacji nowości normatywnej nieprzewidzianej aktem tworzenia prawa. Monopol na definiowanie treści normatywnych ma prawodawca, który kreuje prawo po to, by sterować procesami społecznymi w skali globalnej. Konsekwencją pojmowania prawa jako narzędzia globalnej przebudowy społecznej jest postulat wykluczenia przynajmniej części aktów wewnętrznych z zakresu pojęcia prawa ${ }^{79}$;

e) systemowość prawa jest założona zarówno w pojęciu normy obowiązującej, jak i w pojęciu prawa obowiązującego. Norma obowiązująca to norma generalna, która spełnia kryteria określone przez pojęcie obowiązywania systemowego. Pojęcie obowiązywania systemowego funkcjonuje w charakterze reguły uznania, czyli reguły określającej podstawowe kryteria rozstrzygania o tym, która norma

79 J. Wróblewski, Ustawa o tworzeniu..., s. 28-30. 
jest, a która nie jest prawem obowiązującym. Pojęcie obowiązywania systemowego zakłada, że norma może istnieć (obowiązywać) tylko jako element systemu prawa. Pojęcie obowiązywania systemowego wyznacza podstawowe granice prawa obowiązującego. Prawo obowiązujące tworzą normy ustanowione przez kompetentnego prawodawcę (system LSLE) oraz ich logiczne lub quasi-logiczne konsekwencje (LSFC). Konieczność tetyczna (akt stanowienia) oraz konieczność logiczna (bycie logiczną konsekwencją normy ustanowionej przez prawodawcę) decydują zatem o uznaniu normy za wchodzącą w zakres prawa obowiązującego. Pojęcie prawa obowiązującego określa koncepcja systemu LSFC (prawo stanowione plus logiczne konsekwencje prawa stanowionego). Poza granicami prawa obowiązującego są normy określone przez pojęcie systemu LSOL (prawo operatywne), systemu LSIC (prawo zinterpretowane) oraz systemu LSPP (system obejmujący standardy niebędące wynikiem aktu stanowienia, które obowiązują w sensie faktycznym i/ lub aksjologicznym). We wszystkich wymienionych przypadkach o ich wyłączeniu poza obszar prawa obowiązującego przesądza fakt, że o uznaniu normy za element systemu prawa decyduje podmiot inny niż prawodawca (organ stosujący prawo/interpretator), który kieruje się kryteriami aksjologicznymi lub faktycznymi. Koncepcje systemu LSOL, LSIC, LSPP łączy zatem to, że przełamują monopol prawodawcy na decydowanie o tym, co jest prawem obowiązującym. Uznanie, że to wyłącznie system LSFC (LSLE plus logiczne konsekwencje norm ustanowionych) jest prawem obowiązującym, oznacza przyjęcie wąskiej i dyrektywalnej koncepcji systemu prawa (kryteria obowiązywaniam określa reguła uznania), z jednoczesnym odrzuceniem koncepcji decyzyjnej (kryteria obowiązywania określają decyzje stosowania prawa lub decyzje interpretacyjne);

f) proponowany przez J. Wróblewskiego model wykładni operatywnej jest radykalnie redukcjonistyczny i redukuje przestrzeń swobody interpretatora w zakresie określania znaczenia normy. W tym modelu wykładni zakres swobody interpretatora determinują następujące konieczne presupozycje rozumowań interpretacyjnych:

- norma i system norm istnieje obiektywnie jako fakt dany przez prawodawcę,

- prawo jest faktem imperatywnym, a nie dyskursywnym (interpretacyjnym),

- znaczenie normy jest zawsze, przynajmniej w pewnym zakresie, niezależne od interpretatora, to znaczy zdeterminowane przez akt stanowienia normy przez prawodawcę,

— istnieją powszechne dyrektywy interpretacyjne, które interpretator musi zastosować, jeżeli chce zidentyfikować „rzeczywiste znaczenie normy”, którego zignorowanie jest odstępstwem od prawa obowiązującego,

- istnieje powszechnie akceptowany system wartości wewnętrznych prawa (forma życia), który interpretator musi uwzględnić formułując oceny zrelatywizowane systemowo - jest to warunek jego racjonalności materialnej. 
3. Poziom dyrektyw interpretacyjnych:

a) na poziomie dyrektyw językowych założenie systemowości prawa przejawia się w dyrektywach zakładających określony poziom spójności semantycznej tekstu prawnego (języka prawnego). Oznacza to, że równokształtne wyrażenia w języku prawnym mają to samo znaczenie. Założenie to jest formułowane wprost: „Nie wolno identycznym sformułowaniom w tekście prawnym nadawać różnego znaczenia”, lub pośrednio w dyrektywach określanych jako „domniemanie języka potocznego" i „domniemanie języka prawnego”. W pierwszym przypadku, gdy znaczenie wyrażenia nie jest określone przez język prawny, to zgodnie z domniemaniem języka potocznego należy się jednolicie posługiwać znaczeniem potocznym. W drugim przypadku, gdy znaczenie jest określone (zdefiniowane) przez język prawny, należy się nim posługiwać jednolicie w całym systemie prawa, a nie kreować szczególne znaczenie właściwe dla danej gałęzi prawa lub aktu prawnego. Można to domniemanie określić jako domniemanie uniwersalnego zakresu stosowalności definicji legalnych - w wersji umiarkowanej ograniczone do tak zwanych źródłowych definicji legalnych;

b) na poziomie dyrektyw systemowych podstawowe znaczenie ma dyrektywa niesprzeczności systemu: „Należy tak określać znaczenie normy, aby uniknąć powstania sprzeczności technicznych w systemie prawa”. Przyjęta koncepcja „sprzeczności technicznych” w systemie prawa ludowego ma jednoznaczną konotację filozoficzną (ideologiczną). Dyrektywa ta zakłada, że w systemie prawa ludowego mogą występować sprzeczności techniczne - prima facie (pozorne lub powierzchowne). Oznacza to, że występują one na poziomie sformułowania norm prawnych, powstają w wyniku błędów w technice legislacyjnej. Nie są to sprzeczności prawa lecz sformułowania prawa i jako takie mogą być eliminowane w procesie wykładni. Towarzyszy temu założenie, że w systemie prawa ludowego nie występują sprzeczności polityczne, czyli realne sprzeczności o podłożu klasowym, które są celowo wprowadzane przez prawodawcę. W tym sensie system prawa ludowego jest systemem niesprzecznym, który charakteryzuje wysoki poziom spójności socjologicznej (prawo ludowe jest wyrazem woli klasy postępowej). Pojęcie sprzeczności technicznych obejmuje tak zwaną lukę techniczną rozumianą jako niekompletność regulacji prawnej, która utrudnia lub uniemożliwia podjęcie decyzji. Sprzeczność ta ma również charakter pozorny i podobnie jak pozostałe sprzeczności techniczne może być usuwana w procesie wykładni poprzez zabiegi interpretacyjne obejmujące analogię legis. W tym sensie system prawa ludowego jest zupełny. Wykluczono stosowanie analogii iuris ze względu na jej prawotwórczy charakter. Ujęcie luki technicznej w kategoriach sprzeczności technicznej pomiędzy generalnym nakazem rozstrzygnięcia a zakazem rozstrzygnięcia wynikającym z braku regulacji prawnej, wykazuje jednoznaczną determinację filozoficzną (ideologiczną). Przyjęta konstrukcja teoretyczna zupełności systemu prawa ludowego zakłada pozorność braku regulacji prawnej. Stwierdzany brak regulacji 
prawnej jest pozorny w tym sensie, że tak jak w przypadku każdej sprzeczności technicznej:

— nie jest przez prawodawcę zamierzony,

- jest wynikiem błędów w technice legislacyjnej polegających na niewłaściwym sformułowaniu prawa,

— nie jest związany z realnymi konfliktami politycznymi (klasowymi).

$\mathrm{W}$ konsekwencji, stosowane $\mathrm{w}$ takich przypadkach zabiegi interpretacyjne obejmujące analogię legis nie noszą znamion działalności prawotwórczej, ponieważ nie są wypełnianiem jakiegoś rzeczywistego braku regulacji prawnej, co z konieczności musiałoby mieć charakter prawotwórczy, a tylko korygowaniem błędów legislacyjnych polegających na niewłaściwym sformułowaniu prawa. Przyjęta konstrukcja zupełności systemu prawa ludowego, sprowadzająca luki do pozornych sprzeczności usuwanych przez zabiegi niemające charakteru prawotwórczego, pozwala na poziomie teoretycznym na zachowanie monopolu prawodawcy na tworzenie prawa, który jest przesądzony na poziomie pierwotnych poznawczo założeń filozoficznych. Dla uzupełnienia obrazu konstrukcji teoretycznej zupełności systemu prawa ludowego trzeba dodać, że opiera się ona na trzech założeniach o charakterze normatywnym:

— należy przyjąc ogólną normę wyłączającą, zgodnie z którą to, co nie wywołuje konsekwencji pozytywnych (nakaz, zakaz, dozwolenie), stwarza konsekwencje negatywne (jest prawnie indyferentne) - w następstwie czego stwierdzenie istnienia luki ma zawsze charakter oceniający, a nie opisowy,

- oceniające stwierdzenie luki technicznej powinno być zgodne z systemem wartości wewnętrznych prawa ludowego,

- należy uznać zidentyfikowane oceniająco luki techniczne za pozorne sprzeczności techniczne i rozwiązywać je za pomocą zabiegów nie mających charakteru prawotwórczego;

c) założenie spójności aksjologicznej systemu prawa ludowego występuje na poziomie dyrektyw wykładni systemowej: „Należy tak ustalać znaczenie normy, aby była koherentna $\mathrm{z}$ innymi normami systemu prawa", oraz na poziomie wykładni funkcjonalnej. W tym drugim przypadku chodzi o dyrektywę nakazującą jednolite posługiwanie się ocenami i regułami społecznymi w odniesieniu do norm tworzących instytucję prawną oraz dyrektywę nakazującą posługiwanie się akceptowanym systemem wartości w procesie wykładni. Obie powinny być odczytywane w kontekście ideologii racjonalnej i praworządnej decyzji sądowej. Na gruncie tej ideologii warunkiem koniecznym racjonalności i praworządności interpretatora jest akceptacja systemu wartości wewnętrznych prawa w procesie ustalania znaczenia normy. W tym kontekście ideologicznym zachowanie spójności aksjologicznej systemu prawa jest równoznaczne z zachowaniem systemu wartości wewnętrznych prawa zakodowanego w prawie przez prawodawcę. Na gruncie tej ideologii system wartości wewnętrznych prawa ludowego definiuje akceptowaną formę życia (wol- 
ne od alienacji społeczeństwo komunistyczne) ${ }^{80}$. W konsekwencji, interpretator, ustalając znaczenie normy, może się odwołać do pozaprawnych ocen i reguł społecznych tylko w takim zakresie, w jakim są one zgodne z systemem wartości wewnętrznych prawa ludowego określających zdefiniowaną przez prawodawcę formę życia. Inaczej mówiąc, postulat spójności aksjologicznej systemu prawa wymaga, aby interpretator, dokonując wyborów oceniających, formułował wyłącznie oceny zrelatywizowane systemowo do systemu wartości określonych przez tak zwaną etykę postępu. Ideologia praworządnej i racjonalnej decyzji sądowej gwarantuje spójność aksjologiczną prawa ludowego poprzez nakaz identyfikacji interpretatora z systemem wartości wewnętrznych prawa ludowego, który skutkuje nakazem formułowania przez interpretatora wyłącznie ocen zrelatywizowanych do systemu wartości określonych przez etykę postępu (etykę klasy postępowej, której działania urzeczywistniają obiektywny proces postępu dziejowego). Na gruncie ideologii praworządnej i racjonalnej decyzji sądowej, spełnienie tych postulatów warunkuje racjonalność materialną interpretatora (organu stosującego prawo). Określony na poziomie teoretycznym (poziom dyrektyw wykładni oraz poziom ideologii wykładni) postulat zachowania spójności aksjologicznej systemu prawa jest konsekwencją przyjętych na poziomie filozoficznym rozstrzygnięć zakładających, że prawo ludowe to narzędzie tworzenia bytu wyższego rzędu traktowanego jako najwyższa wartość wyznaczona przez obiektywny proces postępu dziejowego.

Warto powtórzyć, że omawiana teoria wykładni jest teorią wykładni prawa ludowego. Pojęcie prawa ludowego jest kategorią filozoficzną, tzn. że podstawowe cechy prawa ludowego określone są na poziomie rozstrzygnięć filozoficznych. Tak postrzegane prawo ludowe, czyli jako kategoria filozoficzna, a nie empiryczna, jest narzędziem tworzenia wyższej formy bytu (społeczeństwo komunistyczne, w którym nie występują realne sprzeczności polityczne o podłożu klasowym). Wyłączny monopol na posługiwanie się tym narzędziem ma uprzywilejowany poznawczo prawodawca, który legitymację do działań prawotwórczych czerpie z posiadania wyróżnionej wiedzy na temat wyższej formy społecznego istnienia. Prawo jest faktem imperatywnym zdeterminowanym przez prawodawcę, a nie faktem interpretacyjnym konstytuowanym w dyskursie prawniczym. Wszystkie twierdzenia omawianej teorii wykładni są twierdzeniami o interpretacji tak pojmowanego prawa ludowego. Oznacza to, że twierdzenia teorii wykładni presuponują istnienie prawa ludowego o wskazanych wyżej cechach określonych na poziomie dokonanych rozstrzygnięć filozoficznych. W tym sensie twierdzenia filozoficzne określające podstawowe cechy prawa ludowego, są pierwotne poznawczo wobec twierdzeń teoretycznoprawnych na temat prawa i jego wykładni. W szczególności, pierwotne poznawczo założenia filozoficzne determinują określony na poziomie twierdzeń teoretycznoprawnych: (a) sposób pojmowania roli

80 W. Lang, J. Wróblewski, Aksjologia prawa socjalistycznego, passim; por. też J. Wróblewski, Teoria racjonalnego..., s. 230. 
interpretatora, (b) sposób pojmowania systemowości prawa. W pierwszej kwestii, omawiana teoria wykładni określa rolę interpretatora w sposób wyraźnie redukcjonistyczny. Przybiera to postać następujących założeń: (a) monopol prawodawcy na tworzenie prawa obejmuje nie tylko wyłączność na dokonywanie aktów prawotwórczych, lecz także na określanie treści normatywnych, w konsekwencji, należy przyjąć, że w typowych przypadkach znaczenie normy jest określone przez prawodawcę $\mathrm{w}$ stopniu wystarczającym dla potrzeb stosowania prawa, co powoduje zbędność wykładni, ponieważ znaczenie normy może być określone w wyniku bezpośredniego rozumienia tekstu prawnego (tzw. sytuacja izomorfii, w której obowiązuje zasada clara non sunt interpretanda), (b) zdeterminowane przez prawodawcę znaczenie normy jest zawsze, w tym także w sytuacji wykładni, przynajmniej w pewnym stopniu niezależne od interpretatora, (c) w sytuacji wykładni, która jest sytuacją atypową, interpretator nie doprecyzowuje znaczenia normy w sposób dowolny, ponieważ jego aktywność ograniczają z jednej strony powszechnie przyjęte dyrektywy, a z drugiej - powszechnie przyjęte oceny, (d) zgodnie z ideologią praworządnej i racjonalnej decyzji sądowej (interpretacyjnej), w przypadku dokonywania wyborów oceniających, racjonalny interpretator dokonuje wyłącznie ocen zrelatywizowanych do systemu wartości wewnętrznych prawa ludowego określających powszechnie akceptowaną formę życia (wolna od alienacji wyższa forma bytu). W kwestii sposobu pojmowania systemowości prawa, przyjęte rozstrzygnięcia dotyczą takich kwestii, jak: (a) określenie granic systemu prawa, (b) pojmowanie niesprzeczności i zupełności systemu prawa, (c) pojmowanie spójności aksjologicznej systemu prawa. W konsekwencji, założenie systemowości prawa jest podstawowym dla omawianej teorii wykładni. Przejawia się ono nie tylko w dyrektywach wykładni systemowej, lecz także w dyrektywach wykładni językowej i funkcjonalnej. W omawianej teorii wykładni prawo jest systemem zarówno jako punkt wyjścia działań interpretacyjnych (system LSFC prawo obowiązujące), jak i ich rezultat (system LSIC — prawo zinterpretowane).

\section{THE ASSUMPTION OF SYSTEMIC NATURE OF LAW IN JERZY WRÓBLEWSKI'S THEORY OF INTERPRETATION}

\section{Summary}

That is to say that Jerzy Wróblewski's theory of interpretation assumes philosophical attitude consisting in acceptance of Marxist philosophy. Consequently, Jerzy Wróblewski's theory of interpretation may be counted as theory of interpretation of "people's law". The author tends to point out that the notion of "people's law" is a philosophical category, i. e. the main traits of "peoples law" are defined on the level of Marxist philosophy. Consequently, all propositions of Jerzy Wróblewski's theory of interpretation are propositions which presuppose existence of such conceived "people's law". In the article, the author strives to point out that philosophical assumptions of Marxist philosophy determine Jerzy Wróblewski's way of conceiving the systemic character of law. 